\title{
Plasmin improves oedematous blood-gas barrier by cleaving epithelial sodium channels
}

Running title: 16 cuts of human $\gamma \mathrm{ENaC}$ by plasmin

Runzhen Zhao ${ }^{1}$, Gibran Ali $^{1}$, Hong-Guang Nie ${ }^{1,2}$, Yongchang Chang ${ }^{3}$, Deepa Bhattarai ${ }^{1}$,, Xuefeng Su ${ }^{1}$, Xiaoli Zhao $^{4}$, Michael A. Matthay ${ }^{5, *}$, Hong-Long Ji, ${ }^{1,6, *}$

${ }^{1}$ Department of Cellular and Molecular Biology, University of Texas Health Science Centre at Tyler, Tyler, Texas 75708, USA; ${ }^{2}$ College of Basic Medical Science, China Medical University, Shenyang, Liaoning 110001, China; ${ }^{3}$ Barrow Neurological Institute, 350 West Thomas Road, Phoenix, Arizona 85013-4409, USA; ${ }^{4}$ Department of Physiological Sciences, Eastern Virginia Medical School, Norfolk, Virginia 23501, USA; ${ }^{5}$ Department of Medicine and Aneasthesia, University of California San Francisco, San Francisco, California, USA; ${ }^{6}$ Texas Lung Injury Institute, University of Texas Health Science Centre at Tyler, Tyler, Texas 75708, USA

\# Present address: Department of Paediatric Surgery, McGovern Medical School, University of Texas Health Science Centre at Houston. Deepa.Bhattarai@uth.tmc.edu.

Word count: Abstract (272), Introduction (473), Results (1,977), Discussion (886). In total, 3, 336 words for main text.

\section{ACKNOWLEDGEMENTS}

This study was supported by NIH grants HL87017, HL095435, HL134828, AHA14GRNT20130034, NSFC 81670010, and AHA16GRNT30780002. The authors thank Ms. Yun Jiang (University of Texas Health Science Centre at Tyler) and Dr. Steven Idell (University of Texas Health Science Centre at Tyler) for their superb technical support and thoughtful discussion. The authors acknowledge Dr. Andrew Lemoff and Dr. Xuemei Luo of the UTSW Proteomics Core for their professional assistance with mass spectrometry analysis.

\section{CONFLICT OF INTEREST STATEMENT}

All of authors do not have any conflict of interest to clarify.

\section{Correspondence}

Hong-Long (James) Ji, james.ji@uthct.edu; Michael A. Matthay,_michael.matthay@ucsf.edu.

\section{Funding information}

NIH grants: HL87017, HL095435, and HL134828; AHA award: AHA14GRNT20130034 and AHA16GRNT30780002; NSFC fund: 81670010.

Abbreviations: ENaC, epithelial sodium channels; ARDS, acute respiratory distress syndrome; PAI-1, plasminogen activator inhibitor-1; AFC, alveolar fluid clearance; uPA, urokinase plasminogen activator; AT2, alveolar type II epithelial cells; MS, mass spectrometry; GRIP, gating relief of inhibition by proteolysis; AS, amiloride sensitive. 


\section{Bullet point summary}

\section{What is already know}

- Serine proteases proteolytically cleave epithelial sodium channels, including plasmin and uPA acutely.

- Activity of epithelial sodium channels is increased post proteolysis.

\section{What this study adds}

- Plasmin cleaves up to 16 sites composed of two proteolytic centres in both full-length and furin-cleaved human $\gamma$ subunit of epithelial sodium channels in hours.

- Non-proteolytic sites in both $\alpha$ and $\gamma$ subunits interrupt the plasmin cleavage-induced channel gating.

- Intratracheally instilled plasmin facilitates alveolar fluid clearance in normal human and injured mouse lungs.

\section{Clinical significance}

- Activation of human lung epithelial sodium channels by plasmin may benefit lung oedema resolution as a novel therapy for ARDS. 


\begin{abstract}
Background and Purpose: Lung oedema in association with suppressed fibrinolysis is a hallmark of lung injury. We aimed to test whether plasmin cleaves epithelial sodium channels $(\mathrm{ENaC})$ to resolve lung oedema fluid.

Experimental Approaches: Human lungs and airway acid-instilled mice were used for analysing fluid resolution. In silico prediction, mutagenesis, Xenopus oocytes, immunoblotting, voltage clamp, mass spectrometry, protein docking, and alveolar fluid clearance were combined for identifying plasmin specific cleavage sites and benefits.

Key Results: Plasmin led to a marked increment in lung fluid resolution in both human lungs ex vivo and injured mice. Plasmin specifically activated $\alpha \beta \gamma \mathrm{ENaC}$ channels in oocytes in a time-dependent manner. Deletion of four consensus proteolysis tracts $(\alpha \Delta 432-444, \gamma \Delta 131-138, \gamma \Delta 178-193$, and $\gamma \Delta 410-422)$ eliminated plasmin-induced activation significantly. Further, immunoblotting assays identified 7 cleavage sites (K126, R135, K136, R153, $\mathrm{K} 168, \mathrm{R} 178, \mathrm{~K} 179)$ for plasmin to trim both furin-cleaved C-terminal fragments and full-length human $\gamma \mathrm{ENaC}$ proteins. In addition to confirming the 7 cleavage sites, 9 new sites (R122, R137, R138, K150, K170, R172, R180, $\mathrm{K} 181, \mathrm{~K} 189$ ) in synthesized peptides were found to be cleaved by plasmin with mass spectrometry. These cleavage sites were located in the finger and the thumb, particularly the GRIP domain of human ENaC 3D model composed of two proteolytic centres for plasmin. Novel uncleaved sites beyond the GRIP domain in both $\alpha$ and $\gamma$ subunits were identified to interrupt the plasmin cleavage-induced conformational change in $\mathrm{ENaC}$ channel complexes. Additionally, plasmin could regulate $\mathrm{ENaC}$ activity via the $\mathrm{G}$ protein signal.
\end{abstract}

Conclusion and Implications: We demonstrate that plasmin could cleave $\mathrm{ENaC}$ to benefit the blood-gas exchange by resolving oedema fluid as a potent fibrinolytic therapy for oedematous pulmonary diseases.

Keywords: Proteolysis, sodium retention, cleavage sites, pulmonary oedema, fibrinolysis 


\section{INTRODUCTION}

One of the most common complications of sepsis is the acute respiratory distress syndrome (ARDS) with a hallmark of dysfunctional blood-gas barrier, occurring in nearly 200,000 patients per year with a mortality above $30 \%$ (Ware \& Matthay, 2000). ARDS is characterized by hypoxemia with bilateral infiltrates of the lungs with noncardiac origin (Ranieri et al., 2012; Sartori \& Matthay, 2002). Prolonged suppression of normal fibrinolytic activity, paralleled by a sustained increase in plasminogen activator inhibitor-1 (PAI-1) has been consistently observed in clinical and preclinical studies of septic ARDS (Bertozzi et al., 1990). Fibrinolytic activity is further impaired following the development of sepsis with multiorgan failure (Asakura et al., 2001). An elevated plasma PAI-1 concentration is associated with an adverse outcome in sepsis (Hermans et al., 1999). Caged plasminogen activators lose their ability to produce plasmin, a key molecule of the plasminogen/plasmin system that sustains normal fibrinolysis. The reduced fibrinolytic activity was also reported in bronchoalveolar fluid and pleural effusion of septic illnesses (Idell, James \& Coalson, 1992). Concurrently, increased permeability pulmonary oedema often develops. Accumulation of alveolar oedema fluid mainly results from an increase in lung endothelial and epithelial permeability that cannot be compensated by transepithelial fluid re-absorption (Matthay, Folkesson \& Clerici, 2002), causing what is termed clinically ARDS (Matthay, Ware \& Zimmerman, 2012). Epithelial sodium channels $(\mathrm{ENaC})$ located at the apical membrane regulate alveolar fluid reabsorption across the tight alveolar epithelium (Ji, Zhao, Chen, Shetty, Idell \& Matalon, 2012). Reduced ENaC expression and activity are described in both injured human lungs ex vivo and in the animal models of lung injury (Matthay, Folkesson \& Clerici, 2002). Decreased alveolar fluid clearance is confirmed in mice with deficient scnn1 genes. Plasminogen activators may decrease the severity of lung injury and pleural effusion (Karandashova et al., 2013) and may reduce the risk of death from ARDS and multiorgan failure from sepsis (Hardaway, Harke, Tyroch, Williams, Vazquez \& Krause, 2001; Lim \& Chin, 1999). Recently, our meta-analysis reports that fibrinolytic therapy might reduce lung injury, facilitate oedema fluid resolution, and reduced histologic lung injury score in animal models of acute lung injury (Liu et al., 2018). However, whether exogenously administered plasmin enhances the removal of oedema fluid via $\mathrm{ENaC}$ and related mechanisms, is not clear. We recently identified human $\mathrm{ENaC}$ as a novel target of urokinase (Ji, Zhao, Komissarov, Chang, Liu \& Matthay, 2015). Based on the lesser specificity of plasmin substrates in amino acid sequence, it is a challenge to identify all of cleavage sites for plasmin, in particular for in vivo lifetime exposure to plasmin. On the other hand, whether or not plasmin could enhance reduced transepithelial fluid transport and restore impaired alveolar fluid clearance in vivo has not been studied. Therefore, we aimed to test the potential beneficial effects of plasmin delivered intratracheally on alveolar fluid clearance and determined proteolysis as post-translational mechanisms. 


\section{MATERIALS AND METHODS}

\subsection{Reagents}

Human recombined plasmin (Molecular Innovation, Novi, Michigan, USA. Cat\#: HPLM ), two-chain urokinase plasminogen activator (Molecular Innovation, Novi, Michigan, USA. Cat\#: UPA-HTC), dispase (Corning, USA.Cat.\# 354235), DNase I (Sigma-Aldrich, St. Louis, Missouri, USA. Cat\#: DN25), bovine serum albumin (Sigma-Aldrich, St. Louis, Missouri, USA. Cat\#: A2153), biotin rat anti-mouse CD16/32 (BD, Pharmingen, USA. Clone 2.4G2. Cat\#: 553143), biotin rat anti-mouse CD45 (BD, Pharmingen, USA. Clone 30-F11. Cat\#: 553078), biotin rat anti-mouse Ter-119/erythroid TER-119 cells (BD, Pharmingen, USA. Cat\# 553672), Dynabeads ${ }^{\mathrm{TM}}$ MyOne $^{\mathrm{TM}}$ streptavidin T1 magnetic beads (Invitrogen, USA. Cat\#: 65601), mouse IgG (Sigma-Aldrich, St. Louis, Missouri, USA. Cat\# I5381), mouse laminin1 (Trevigen, USA. Cat\#: 3401-010-02), tricaine-S (MS-222) (Western Chemical, Inc. USA), EZ-Link Sulfo-NHS-SS-Biotin (Thermo Scientific, USA. Cat\#: 21331), anti-V5 mouse monoclonal IgG2a antibody (Invitrogen, USA. Cat\#: R960-25), anti-HA high affinity rat monoclonal antibody (Roche USA. Clone 3F10. Cat\#: 11867423001).

\subsection{Animals and $\mathrm{HCl}$ instillation}

Healthy, 8-12-week-old, male or female C57 BL/6 mice (cat\#: 000664, Jackson Lab) were used. Animals were kept under pathogen-free conditions, and all experimental procedures were approved by the Institutional Animal Care and Use Committee of the University of Texas Health Science Center at Tyler. To create an in vivo model of lung injury, anesthetized mice were administered intratracheally (i.t.) $0.1 \mathrm{M} \mathrm{HCl}$ in $2.5 \mu 1 \cdot \mathrm{g}^{-1}$ body weight followed by $30 \mu \mathrm{l} \cdot \mathrm{g}^{-1}$ body weight of air (Nagase et al., 2000; Patel, Wilson \& Takata, 2012). Control mice were administered the same volume of $0.9 \% \mathrm{NaCl}$ and air.

\subsection{In vivo alveolar fluid clearance (AFC) in mice}

In vivo AFC rate was measured in vivo as previously described (Han et al., 2010; Patel, Wilson \& Takata, 2012). Briefly, mice $4 \mathrm{hr}$ post $\mathrm{HCl}$ instillation were anesthesized by ketamine $\left(1.7 \mathrm{mg} \cdot \mathrm{ml}^{-1}\right)$ and xylazine $\left(20 \mathrm{mg} \cdot \mathrm{ml}^{-1}\right)$, at $5 \mathrm{ml} / \mathrm{kg}$ body weight by intraperitoneal injection. Then the mice were placed on a continuous positive airway pressure system delivering $100 \% \mathrm{O}_{2}$ at $8 \mathrm{cmH}_{2} \mathrm{O}$. All animals were maintained at a temperature of $37{ }^{\circ} \mathrm{C}$ with a heating pad and ultrared bulb. An isosmotic instillate containing $5 \%$ bovine serum albumin was prepared with $0.9 \% \mathrm{NaCl}$ as base solution. Control animals were intratracheally delivered with $50 \mu \mathrm{l}$ the base solution. Plasmin (one group with $60 \mu \mathrm{g} \cdot \mathrm{ml}^{-1}$ and another group with $100 \mu \mathrm{g} \cdot \mathrm{ml}^{-1}$ ), a mixture of plasmin and equal amount of $\alpha 2$ antiplasmin $(\mathrm{Pl}+\mathrm{AP})$, and plasmin $\left(60 \mu \mathrm{g} \cdot \mathrm{ml}^{-1}\right)$ in the presence of amiloride $(1 \mathrm{mM})$ were intratracheally delivered. To maximize the collection of instilled BSA solution, the diaphragm was dissected post 30 min ventilation. Methodological concerns were addressed by using amiloride to inhibit water movement to confirm that measurements accurately reflected AFC. With the assumption that the concentration of instilled BSA proteins is not altered significantly by the presence of excess alveolar fluid and/or protein caused by HCl-induced damage. $\mathrm{HCl}$ may impair the blood-gas barrier function and causes a significant leakage of murine serum proteins into the air space. The endogenous BSA may lead to an overestimation of AFC rates. This potential bias was corrected by measuring murine albumin (cat\#: EMA3201-1, AssayPro, St. Charles, MO) and bovine albumin (cat\#: E10-113, Bethyl Laboratories, Montgomery, TX) separately using specific ELISAs following the manufacturer's instructions (Wolk et al., 2008). Final AFC values were corrected by removing murine albumin present in the aspirate. In addition, we used an aliquot of the instillate that had been delivered into the lungs and removed within $5 \mathrm{~min}$, rather than freshly prepared naive instillate per se. Any pre-existing oedema or leaking murine plasma proteins would be excluded for it dilutes both the control at time point $0 \mathrm{~min}\left(P_{i}\right)$ and final samples $\left(P_{f}\right)$. The calculation of AFC was same as described for human lungs below.

\subsection{Ex vivo human lung lobe studies}

Discarded human lung lobes more than $5 \mathrm{~cm}$ away from tumor were collected $24 \mathrm{hr}$ post-surgery with an approved exempt from the IRB committee of the China Medical University. The left and right lobes were chosen randomly 
upon availability. Lung lobes were ventilated with $100 \% \mathrm{O}_{2}$ via a volume-controlled ventilator (model 683, Harvard Apparatus) and were passively rewarmed at $37{ }^{\circ} \mathrm{C}$ for $1 \mathrm{hr}$ without perfusion in an incubator prior to measuring AFC. Plasmin $\left(60 \mu \mathrm{g} \cdot \mathrm{ml}^{-1}\right)$ was added to the instillate $(20 \mathrm{ml})$ and intrabronchially delivered. The instilled alveolar fluid was aspirated by applying gentle suction to the tracheal catheter with a 1-ml syringe. The BSA content of the alveolar fluid was measured with a 96-well microplate reader. AFC was calculated as follows: $A F C=\left(V_{i}-V_{f}\right) / V_{i} \times 100$, where $V_{i}$ and $V_{f}$ denote the volume of the instilled and recovered alveolar fluid, respectively. $V_{f}$ was obtained as $V_{f}=\left(V_{i} \times P_{i}\right) / P_{f}$, where $P_{i}$ and $P_{f}$ represent protein concentration of instilled and collected fluid.

\subsection{Primary type 2 alveolar epithelial cell (AT2) culture and bioelectrical measurements}

Mouse AT2 cells were isolated from both wt and uPA knockout (plau ${ }^{-/}$) strains of C57BL/6 mice (cat\#: 000664 and 002509, respectively. Jackson Laboratory, USA) with a modified protocol as described (Demaio et al., 2009; Zhao et al., 2019). Briefly, lungs of euthanized mice were removed and incubated in dispase for $45 \mathrm{~min}$, and then were gently teased and incubated in DMEM/F-12+0.01\% DNase I for $10 \mathrm{~min}$. Cells were passed through a serial of Nitex filters (100, 40, 30, and 10 microns; Corning, USA) and centrifuged at $300 \mathrm{~g}$ for $10 \mathrm{~min}$. Resuspended cells were biotinylated with CD16/32 $\left(0.65 \mu \mathrm{g} \cdot 10^{-6}\right.$ cells $)$, CD45 $\left(1.5 \mu \mathrm{g} \cdot 10^{-6} \mathrm{cells}\right)$ and Ter/119 $\left.(10 \mu \mathrm{l})\right)$ antibodies and then incubated with streptavidin-coated magnetic particles $\left(2.5 \mu \mathrm{g} \cdot 10^{-6} \mathrm{cells}\right)$. Fibroblasts were removed by a $2 \mathrm{hr}$ incubation in a mouse IgG coated plastic culture dish. Upon passing the request for both viability $(>90 \%)$ and purity assays (>95\%), mouse laminin 1 precoated transwells (cat\#: 3413, Corning Costar, USA) were seeded with AT2 cells $\left(10^{6}\right.$ cells per $\left.\mathrm{cm}^{2}\right)$. Culture medium was replaced post $72 \mathrm{hr}$ and then every $48 \mathrm{hr}$. Transepithelial resistance $\left(\mathrm{R}_{\mathrm{TE}}\right)$ and potential difference $\left(\mathrm{V}_{\mathrm{TE}}\right)$ were measured using an epithelial voltohmmeter (World Precision Instrument, USA). Equivalent short-circuit current $\left(\mathrm{I}_{\mathrm{EQ}}\right)$ values were calculated as the ratio of $\mathrm{V}_{\mathrm{TE}} / \mathrm{R}_{\mathrm{TE}}$.

\subsection{Construction of ENaC mutants}

Deletion and site-directed mutants were generated in human ENaC cDNAs cloned into a pGEM HE vector using the QuikChange II Site-Directed Mutagenesis kit (Stratagene) (Ji \& Benos, 2004; Molina et al., 2011). cRNAs of human $\alpha, \beta$, and $\gamma \mathrm{ENaC}$ subunits were prepared as described previously (Ji, Parker, Langloh, Fuller \& Benos, 2001). HA and V5 tags were introduced to the $\mathrm{N}$ and C-termini of $\alpha$ and $\gamma \mathrm{ENaC}$ subunits, respectively.

\subsection{Oocyte expression and voltage clamp studies}

Xenopus oocytes were surgically removed from appropriately anesthetized adult female Xenopus laevis (cat\#: HCG IMP FM, hCG injected Mature Female Xenopus laevis, Xenopus Express) as described (Zhao et al., 2019). Briefly, the ovarian tissue was removed from frogs under anaesthesia by $0.1 \%$ of Tricaine through a small incision in the lower abdomen. Ovarian lobes were removed and digested in OR-2 calcium-free medium (in mM: 82.5 $\mathrm{NaCl}, 2.5 \mathrm{KCl}, 1.0 \mathrm{MgCl}_{2}, 1.0 \mathrm{Na}_{2} \mathrm{HPO}_{4}$, and 10.0 HEPES, $\left.\mathrm{pH} 7.5\right)$ with the addition of $2 \mathrm{mg} \cdot \mathrm{ml}^{-1}$ collagenase (Roche, Indianapolis). Defolliculated oocytes were injected with ENaC cRNAs into the cytosol (25 ng per oocyte in $50 \mathrm{nl}$ of RNase-free water) and incubated in regular OR-2 medium at $18{ }^{\circ} \mathrm{C}$. The two-electrode voltage clamp technique was used to record whole-cell currents $48 \mathrm{hr}$ post injection. Oocytes were impaled with two electrodes filled with $3 \mathrm{M} \mathrm{KCl}$, having resistance of $0.5-2 \mathrm{M} \Omega$. A TEV-200A voltage clamp amplifier (Dagan) was used to clamp oocytes with concomitant recording of currents. Two reference electrodes were connected to the bath. The continuously perfused bathing solution was ND-96 medium (in mM: $96.0 \mathrm{NaCl}, 1.0 \mathrm{MgCl}_{2}, 1.8 \mathrm{CaCl}_{2}, 2.5 \mathrm{KCl}$, and 5.0 HEPES, pH 7.5). Whole-cell currents were recorded as previously reported (Ji et al., 2006). Experiments were controlled by pCLAMP 10.7 software (Molecular Devices), and currents were continuously monitored at an interval of $10 \mathrm{sec}$. To analyse amiloride inhibition, we waited until the current level reduced and reach a plateau and last for at least $1 \mathrm{~min}$. after amiloride application to the bath Data were sampled at the rate of $200 \mathrm{~Hz}$ and filtered at $50 \mathrm{~Hz}$.

\subsection{Biotinylation and immunoblotting}


Biotinylation experiments were adapted from previous publications (Haerteis, Krappitz, Diakov, Krappitz, Rauh \& Korbmacher, 2012; Haerteis, Krueger, Korbmacher \& Rauh, 2009), using 20-40 oocytes per group. In some experiments, oocytes were preincubated either in ND-96 solution or low sodium solution ( $1 \mathrm{mM} \mathrm{NaCl}, 96 \mathrm{mM}$ NMDG). Oocytes were incubated in freshly prepared biotinylation buffer $\left(1.5 \mathrm{mg} \cdot \mathrm{ml}^{-1}\right.$ EZ-Link Sulfo-NHS-SSBiotin in DPBS solution from Hyclone, $\mathrm{pH} \mathrm{8.0)} \mathrm{for} 30 \mathrm{~min}$ at room temperature with gentle agitation. The biotinylation reaction was stopped by washing the oocytes three times for 5 min each with quenching buffer (in $\mathrm{mM}$ : $192 \mathrm{mM}$ glycine and $25 \mathrm{mM}$ Tris-Cl, $\mathrm{pH}$ 7.5). Subsequently, the oocytes were incubated in ND-96 solution or supplemented with $10 \mu \mathrm{g} \cdot \mathrm{ml}^{-1}$ human plasmin for $60 \mathrm{~min}$ or designated periods for time-dependent study. After washing the oocytes three times with ND-96 solution, treated cells were lysed by passing them through a 27-gauge needle in lysis buffer (in mM: $500 \mathrm{mM} \mathrm{NaCl}, 5 \mathrm{mM}$ EDTA, $50 \mathrm{mM}$ Tris, 1\% Triton X-100, 1\% Igepal CA-630, pH 7.4) and supplemented with Complete Mini EDTA-free protease inhibitor cocktail (Roche, 04693159001 ) according to the manufacturer's instructions. The lysates were incubated in a shaker for $1 \mathrm{hr}$ and centrifuged at $16,000 \times \mathrm{g}$ for $15 \mathrm{~min}$ at $4{ }^{\circ} \mathrm{C}$. Supernatants were transferred to $1.5-\mathrm{ml}$ tubes (Eppendorf). Biotinylated proteins were precipitated with $50 \mu 1$ of pre-washed high capacity neutravidin agarose resin (Pierce, 29204). After overnight incubation at $4{ }^{\circ} \mathrm{C}$ with overhead rotation, supernatants were removed, and beads were washed three times with lysis buffer containing protease inhibitors. $50 \mu 1$ of $2 \times$ SDS-PAGE sample buffer (Pierce, 39001 ) was added to the beads. Samples were boiled for $5 \mathrm{~min}$ at $95^{\circ} \mathrm{C}$, centrifuged for $1 \mathrm{~min}$ and loaded on a 7.5\% SDS-PAGE gel. To detect small peptides by anti-HA antibody, samples were run on a 16.5\% Tris-Tricine gel (BioRad, 4563063) for some experiments. To detect $\gamma \mathrm{ENaC}$ fragments, the membrane blots were blocked in $5 \%$ blocking buffer ( $5 \%$ non-fat dry milk, Bio-Rad, in TBST) for $1 \mathrm{~h}$ at room temperature. Then, anti-V5 or antiHA monoclonal ) antibodies were added to the samples (1:5,000 and 1:1,000 dilution, respectively). Our and other groups have demonstrated that non-ENaC bands could be detected in parental oocytes or oocytes expressing $\mathrm{ENaC}$ constructs without these artificial flags (Carattino et al., 2014; Ji, Zhao, Komissarov, Chang, Liu \& Matthay, 2015; Passero, Mueller, Myerburg, Carattino, Hughey \& Kleyman, 2012; Passero, Mueller, Rondon-Berrios, Tofovic, Hughey \& Kleyman, 2008). Horseradish peroxidase-labelled secondary antibodies (Jackson Immunoresearch) were used $(1: 10,000)$. Chemiluminescence signals were detected using ECL Plus (Millipore).

\subsection{In silico prediction of plasmin cleaved sites in $\alpha, \beta, \gamma$, and $\delta \mathrm{ENaC}$ subunits}

Specific cleavage sites for human plasmin confirmed with phage substrate display and solution phase fluorogenic peptide microarray (Gosalia, Salisbury, Maly, Ellman \& Diamond, 2005; Hervio, Coombs, Bergstrom, Trivedi, Corey \& Madison, 2000) were applied. Another substrate motif from P4 to P4' was from the getMerops of the SitePrediction server (Verspurten, Gevaert, Declercq \& Vandenabeele, 2009). Default settings of the server were used. The predicted sites must meet these criteria: 1) the cleavage sites are located at the ectodomain of ENaC, 2) the size of predicted C-terminal fragments is similar to that on Western blots or smaller considering potential multiple proteolysis, 3) the P1 protein must be either Arg (R) or Lys (K), 4) average score is $>1$, 5) specificity is > $95 \%$, and 6) predicted by applying both optimized substrate sequences.

\subsection{Mass spectrometry analysis for plasmin cleaved fragments}

Three pure peptides (with a purity $>95 \%$ ) with a continuous sequence from amino acid residue T121 to A190 of the human $\gamma \mathrm{ENaC}$ proteins were synthesized by the GenScript (NJ, USA). The N- and C-termini were acetyled and amidated, respectively. The sequence of each peptide was show in Figure 8a. The synthesized peptides were dissolved in $400 \mu \mathrm{l}$ DPBS $\left(1.0 \mathrm{mg} \cdot \mathrm{ml}^{-1}\right)$, which was digested by adding $10 \mu \mathrm{g} \cdot \mathrm{ml}^{-1}$ plasmin for $30 \mathrm{~min}$ at room temperature. Trifluoroacetic acid $(0.1 \%)$ was used to inactivate cleavage process. The samples were analysed by the University of Texas Southwest Medical Center Proteomics Core. Data were then analysed with the Proteoe Discoverer 2.2 software (Thermo Fisher, USA) based on a tryptic digestion with a maximum of 6 missed cleavages at amino acid residues $\mathrm{R}$ and $\mathrm{K}$. F and $\mathrm{V}$ sites are searched by the strategy for non-specific cleavage. The frequency of the fragments with cleaved end of a specific amino acid residue is the sum of peptide spectral matches for both termini.

\subsection{Statistical analysis}


All results were presented as mean $\pm \mathrm{S}$.E. ENaC activity is the difference of the total and amiloride-resistant current fractions. One-way ANOVA computation combined with the Bonferroni test was used to analyse the difference of the means for significance. $\mathrm{P}<0.05$ was considered significant.

\subsection{Nomenclature of targets and ligands}

Key protein targets and ligands in this article are hyperlinked to corresponding entries in http://www.guidetopharmacology.org, the common portal for data from the IUPHAR/BPS Guide to PHARMACOLOGY (Harding et al., 2018), and are permanently archived in the Concise Guide to PHARMACOLOGY 2017/18 (Alexander et al., 2017). 


\section{RESULTS}

\subsection{Plasmin increases alveolar fluid clearance in healthy human lungs}

The beneficial effects of plasminogen activators on septic respiratory dysfunction imply that plasmin might improve AFC via the ENaC pathway (Chen et al., 2014; Liu et al., 2018). To address this issue, the effects of plasmin on ENaC-mediated fluid resolution were measured in ventilated ex vivo human lung lobes (Figure 1a). Plasmin significantly increased overall AFC value from $14 \%$ in control lobes to $37 \%$ in treated lobes $(\mathrm{P}<0.05)$ in $1 \mathrm{hr}$. Approximately $75 \%$ of the AFC rate was ENaC-dependent, the fraction that was inhibited by amiloride. As reflected by the proportion of amiloride-inhibitable AFC, plasmin stimulated ENaC activity up to 3 times (Figure 1b).

\subsection{Plasmin increases alveolar oedema fluid clearance in the mouse model of injured lungs}

We postulated that plasmin could restore the impaired $\mathrm{ENaC}$ function in a mouse model of gastric acid aspiration (Nagase et al., 2000). Intratracheal administration of two boluses of plasmin $1 \mathrm{hr}$ post $\mathrm{HCl}$ instillation significantly reduced lung water content of injured mouse lungs (Figure 2a). In contrast, deactivation of the catalytic activity of plasmin with specific $\alpha 2$-antiplasmin or amiloride did not alter the wet/dry ratio significantly. Correspondingly, in vivo AFC rate was restored close to a near normal level by proteolytically active plasmin but not by the mixture of plasmin with either $\alpha 2$-antiplasmin or amiloride (Figure $2 \mathrm{~b}$ ). Together with the results in ex vivo human lungs, these data suggest that plasmin may resolve oedema fluid via the $\mathrm{ENaC}$ pathway in injured lungs.

\subsection{Plasmin stimulates deficient ENaC activity in primary AT2 monolayers}

Plasmin exhibited multifaceted effects on membrane-arched receptors and enzymatic substrates in epithelial and nonepithelial cells (Castellino \& Ploplis, 2005; Schaller \& Gerber, 2011). To further confirm the stimulatory effects of plasmin on ENaC function located at the apical membrane of alveolar epithelial cells, we applied plasmin to polarized primary AT2 cell monolayers. As shown in Figure 3a-b, a significant suppression in ENaC activity accompanied by an increment in transepithelial resistance was seen in plau $^{-/}$deficient monolayers, an in vitro model of lung injury mimicking eliminated fibrinolytic activity in injured lungs. The reduced ENaC function was recovered by a bolus of plasmin (Figure 3c). Combined with our previous studies in plau $^{-/}$mice and other groups' observations on the regulation of ENaC by plasmin (Chen et al., 2014; Haerteis, Krappitz, Diakov, Krappitz, Rauh \& Korbmacher, 2012; Ji, Zhao, Komissarov, Chang, Liu \& Matthay, 2015; Passero, Mueller, Rondon-Berrios, Tofovic, Hughey \& Kleyman, 2008), we set up to examine the post-translational mechanisms for plasmin to augment human $\alpha \beta \gamma \mathrm{ENaC}$ channels heterologously expressed in Xenopus oocytes.

\section{$3.4 \gamma \mathrm{ENaC}$ is targeted by plasmin}

Plasmin is generated from plasminogen, a substrate of both tissue-type and urokinase-like plasminogen activators (tPA and uPA, respectively). To examine the effects of plasmin on $\mathrm{ENaC}$ activity, we incubated cells heterologously expressing human $\alpha \beta \gamma \mathrm{ENaC}$ with plasmin for $1 \mathrm{hr}$ with $\mathrm{uPA}$ as a positive control (Ji, Zhao, Komissarov, Chang, Liu \& Matthay, 2015) (Figure 4a). Plasmin activated ENaC currents to approximate $35 \mu \mathrm{A}$ from $5 \mu \mathrm{A}$, which was more potent than tc-uPA. In sharp contrast, the mixture of plasmin and $\alpha 2$-antiplasmin did not affect ENaC current. Plasmin activated human heterologous $\alpha \beta \gamma \mathrm{ENaC}$ activity in a time-dependent manner. The channel activity was activated maximally in $1 \mathrm{hr}$ (Figure 4b). Subsequently, ENaC function declined but still maintained at a level significantly greater than controls within $8 \mathrm{hr}$. To identify what subunit was targeted by plasmin, the stimulatory effects of plasmin on $\mathrm{ENaC}$ channels comprised of $\alpha$ subunit alone, $\alpha+\beta$ subunits, and $\alpha+\gamma$ subunits were analysed with $\alpha \beta \gamma$ channels as a positive control (Figure $4 \mathrm{c}$ ). Both current amplitude and fold of $\alpha \gamma \mathrm{ENaC}$ increased by plasmin significantly, implying that $\gamma$ subunit could be targeted by plasmin (Figure 4d). In contrast, the currents of $\alpha$ alone and $\alpha+\beta \mathrm{ENaC}$ channels were not significantly altered by plasmin. Further, with chymotrypsin as a positive control, we examined potential proteolytic cleavage of $\alpha$ and $\gamma \mathrm{ENaC}$ subunits with immunoblotting assays (Figure $4 \mathrm{e}-\mathrm{h}$ ). Both $\mathrm{N}$ - and C-terminal fragments were detected by anti-HA and anti- 
V5 monoclonal antibodies, respectively. As reported previously (Carattino, Sheng, Bruns, Pilewski, Hughey \& Kleyman, 2006), full-length $\alpha \mathrm{ENaC}$ subunit ( $90 \mathrm{kDa}$ ) was cleaved by endogenous proteases (i.e., furin) into two fragments in control group (Figure 4e-f). Neither plasmin nor chymotrypsin altered furin-cleaved V5- (64 kDa,) and HA-tagged fragments $(26 \mathrm{kDa})$. In sharp contrast, plasmin and chymotrypsin reduced the furin-cleaved Cterminal fragment $(80 \mathrm{kDa})$ of full-length $\gamma \mathrm{ENaC}$ proteins $(90 \mathrm{kDa})$ to $70 \mathrm{kDa}$ (Figure $4 \mathrm{~g}$ ). The N-terminal fragment $(26 \mathrm{kDa})$ as recognized by anti-HA antibody was not affected by both plasmin and chymotrypsin (Figure 4h). Consistent with our previous studies, serine proteases are unable to cleave full-length ENaC (Ji, Zhao, Komissarov, Chang, Liu \& Matthay, 2015). These functional and immunoblotting data indicate that plasmin may specifically activate human $\alpha \beta \gamma$ channels by targeting $\gamma$ subunits proteolytically, and that plasmin as well as chymotrypsin may not be able to cleave the HA-tagged $\mathrm{N}$-terminal fragments of both $\alpha$ and $\gamma$ subunits cut off by furin.

\subsection{Plasmin-mediated regulation of deletion and site-directed mutants missing putative cleavage domains}

Three consensus domains at the extracellular loop for proteases to cleave $\mathrm{ENaC}$ proteins have been proposed (Kleyman, Carattino \& Hughey, 2009; Planes \& Caughey, 2007; Rossier \& Stutts, 2009). We attempted to find potential putative tracts responsible for plasmin-mediated cleavage in both $\alpha$ and $\gamma$ subunits. As shown in Figure 5a, removal of the first (aa173-178) and second (aa201-204) putative cleavage domains in the finger of $\alpha \mathrm{ENaC}$ slightly but not significantly reduced and augmented the stimulation of plasmin on $\mathrm{ENaC}$ function, respectively. By comparison, deletion of the third consensus cleavage tract (aa432-444) in the thumb markedly eliminated plasmin-induced up-regulation of the channel activity (Table 1 and Figure 5a). Similarly, all of three deletion mutants of $\gamma \mathrm{ENaC}$ subunit almost lost their responses to plasmin (Figure 5b). In sharp contrast, plasmin-cleaved C-terminal peptides with variant sizes were seen for these $\gamma$ deletion mutants (Figure 5c-f). Intriguingly, this process might not be furin cleavage-dependent because plasmin was still able to cleave $\gamma \Delta 131-138$, which lost furin cleavage sites-R135K136 (Figure 5d). Plasmin was reported to potentially cleave both human and mouse $\gamma \mathrm{ENaC}$ subunit (Haerteis, Krappitz, Diakov, Krappitz, Rauh \& Korbmacher, 2012; Passero, Mueller, RondonBerrios, Tofovic, Hughey \& Kleyman, 2008). Mutation of mouse $\gamma$ K194 significantly suppressed acute activation of heterologous mouse $\alpha \beta \gamma$ ENaC channels in minutes (Passero, Mueller, Rondon-Berrios, Tofovic, Hughey \& Kleyman, 2008). Substitution of the corresponding site in human $\gamma \mathrm{ENaC}$ subunit $(\gamma \mathrm{K} 189 \mathrm{~A})$ with alanine, however, could not prevent the stimulatory effects of plasmin on human $\alpha \beta \gamma \mathrm{K} 189 \mathrm{~A}$ channels (Figure $5 \mathrm{~g}$ ). Instead, both the domains for mouse plasmin- and prostasin-induced cleavage in human $\gamma \mathrm{ENaC}$ subunit termed $\gamma 5 \mathrm{~A}$ $\left(\mathrm{RKRK}^{178-181} \mathrm{AAAA}+\mathrm{K} 189 \mathrm{~A}\right)$ were crucial for plasmin to acutely activate human $\alpha \beta \gamma$ function (Haerteis, Krappitz, Diakov, Krappitz, Rauh \& Korbmacher, 2012). Surprisingly, plasmin still increased the current amplitude of this $\alpha \beta \gamma 5 \mathrm{~A}$ channels approximate 9 and 20 times in 1 and $24 \mathrm{hr}$, respectively (Figure 5h). Meanwhile, the plasmin-cleaved C-terminal fragments were recognized by anti-V5 antibody (Figure 5i), suggesting additional new cleavage sites exist beyond these 5 amino acid residues for long-term exposed plasmin.

\subsection{Identification of novel critical domains for activation of ENaC by plasmin}

To identify substrate-like motifs in the $\gamma \mathrm{ENaC}$ proteins, we carried out in silico predictions with the SitePrediction server with two different strategies (Figure 6a). Because plasmin cleaved both full-length and furin-catalysed proteins as shown in Figure 5d, we simplified our study by using the furin-site deletion mutant, $\gamma \Delta 131-138$ as a base construct to prepare a new triple mutant, namely, $\gamma \Delta 131-138+3 \mathrm{~A}(\mathrm{~K} 168 \mathrm{~A}, \mathrm{R} 178 \mathrm{~A}, \mathrm{~K} 179 \mathrm{~A})$. These three predicted sites were top ranked by the SitePrediction server. As shown in Figure 6b, the activity of this mutant was not activated by plasmin in both 1 and $24 \mathrm{hr}$. The cleaved C-terminal fragments were not recognized compared with that of $\alpha \beta \gamma \Delta 131-138$ (Figure 6c). Moreover, three single point mutants were made: $\gamma \Delta 131-138+$ K168A, $\gamma \Delta 131-138+\mathrm{R} 178 \mathrm{~A}, \gamma \Delta 131-138+\mathrm{K} 179 \mathrm{~A}$. The activity of these site-directed mutants was no longer elevated by plasmin (Figure 6d). Immunoblotting assays showed a significant reduction in the fraction of cleaved proteins accompanied by increased full-length bands (Figure 6e). Similarly, the densitometry ratio of cleaved bands over full-length bands was marked reduced for these single site-directed mutants (Figure 6f). 
Different size of cleaved band of $\gamma \Delta 178-193$ mutant by plasmin indicates additional cleavage sites may exist. Based on the prediction (Figure 7a), we constructed a new mutant termed $\gamma \Delta 178-193+4 \mathrm{~A}(\mathrm{~K} 126 \mathrm{~A}, \mathrm{R} 135 \mathrm{~A}$, K136A, and R153A). The activity of this mutant was not activated by plasmin (Figure 7b, Table 1). Moreover, the "full-length" proteins of this mutant were increased significantly compared with the $\gamma \Delta 178-193$ mutant (Figure 7c). This was further confirmed by the densitometrical ratio of cleaved/full-length proteins (Figure 7d), suggesting that plasmin could cleave multiple sites in the finger domain of $\gamma \mathrm{ENaC}$ (Figure 7e).

\subsection{Validation of plasmin cleavage sites by mass spectrometry (MS)}

To corroborate identified cleavage sites, three synthesized peptides identical to the sequence of $\gamma \mathrm{ENaC}$ from ${ }^{121} \mathrm{~T}$ to $\mathrm{A}^{190}$ amino acid residues were treated with plasmin and analysed by LC-MS. In addition to confirming the identified critical residues, nine more cleavage sites were detected (Figure 8a and Table 1). The frequency for the fragments with either the $\mathrm{R}$ or $\mathrm{K}$ amino acid residue as the $\mathrm{C}$-terminal tail or the next amino acid residue as the N-terminal tail was computed, the confirmed 7 cleavage sites identified by mutagenesis and confirmed by MS occurred more than 200 times. In comparison, the frequency of most MS discovered new cleavage sites was less than 100 except R122, K170, R180, and K189 (Figure 8a). Representative MS1 spectrum of seven fragments were shown in Figure 8b-h. In general, 4-5 isotopes with variant intensity/counts for the same fragment were seen. Corresponding MS/MS spectrum for these fragments was included in the Supplementary data (Figures S1S7).

\subsection{Identified cleavage sites for plasmin compose two proteolytic centres}

To address the hypothesis that the identified 16 sites may be comprise of cleavage centres spatially in 3D structure (Figure 9a), we labeled three deletion mutants in key domain organization scheme (Figure 9b) and GRIP domain (Figure 9c) based on the cryo-EM model (Noreng, Bharadwaj, Posert, Yoshioka \& Baconguis, 2018). Apparently, one center was made up of six cleavage sites at the end of $\alpha 1$ helix and another with cleavage sites located in antiparallel P1 and P2 strands. On the other hand, we employed protein docking approach to substantiate this notion and potential interactions between individual amino acid residue. We generated a homology model of human $\gamma \mathrm{ENaC}$ with the I-TASSER server (Figure S8a)(Noreng, Bharadwaj, Posert, Yoshioka \& Baconguis, 2018; Roy, Kucukural \& Zhang, 2010). There were three highly accessible clusters of positively charged residues in the GRIP domain of the $\gamma \mathrm{ENaC}$ (Figure S8b). As positive control, Figure S9c-d show interactions between plasmin and two arginine residues (R17 and R19) of textilinin-1 (pdbID: 3uir). Using the interacting residues in plasmin, we found the best docking result between 178RKRK in $\gamma \mathrm{ENaC}$ and D735 and G764 of plasmin (Figure S8e-f). Further, interactions between 135RKRR of $\gamma \mathrm{ENaC}$ and plasmin (Figure S8g-h). Together, two spatial centres for the cleavage by plasmin are identified in the vicinity of $\alpha 1$ terminal and antiparallel P1/P2 strands.

\subsection{G protein pathway may be involved}

$\mathrm{ENaC}$ was regulated by $\mathrm{G}$ proteins, which were downstream molecules of the plasmin signal pathway (Greenlee et al., 2013). Because the effects of plasmin lasted up to $24 \mathrm{~h}$, plasmin could regulate ENaC via activation of the $\mathrm{G}$ protein signal. To exclude this possibility, pertussis toxin was used to specifically inactivate Gi/o activity. Activation of ENaC currents by uPA and plasmin was not affected significantly (Figure S9a). However, the fold of plasmin-activated current was significantly reduced compared with controls and uPA groups (Figure S9b). These data suggest that plasmin but not $\mathrm{uPA}$ could activate $\mathrm{ENaC}$ by activating the $\mathrm{G}$ protein signal pathway as a long-term effect. 


\section{DISCUSSION}

Given the pharmaceutical features of plasmin and depressed fibrinolytic activity in ARDS, we set out to address the hypothesis that plasmin could improve AFC by cleaving ENaC proteolytically. We hereby provide preclinical evidence showing that intratracheally administered plasmin augmented AFC in both normal and acid aspiration injured lungs. For the first time, we found that plasmin catalysed both full-length and furin-trimmed human $\gamma \mathrm{ENaC}$ proteins. Plasmin may be a newly identified pharmaceutical intervention for removing oedema fluid from the air spaces in ARDS.

We identified novel cleavage sites for plasmin beyond three putative regions described previously (Kleyman, Carattino \& Hughey, 2009; Planes \& Caughey, 2007; Rossier \& Stutts, 2009) (Table 1). The GRIP domain (gating relief of inhibition by proteolysis) is comprised of four $\beta$ strands (refereed as P1-4 segments) (Figure 9a \& d)(Noreng, Bharadwaj, Posert, Yoshioka \& Baconguis, 2018). Plasmin cleaved 16 sites, at least two of them are out of this GRIP domain but within the $\alpha 1$ helix of the finger. The antiparallel arrangement of P1 strand, P2 strand, and the $\alpha 1$ helix place all of plasmin cleavage sites in close proximity to facilitate proteolytic efficiency of plasmin by forming two proteolytic centres. Plasmin is the most powerful serine protease and shares cleavage sites with prostasin, trypsin I and IV, uPA, elastases, chymotrypsin, and furin.

One of our novel observations is that long-term exposure of human ENaC proteins to plasmin leads to the cleavage of full-length $\gamma \mathrm{ENaC}$. The current concept is that serine proteases could not cleave full-length ENaC but furin-cut C-terminal fragment potentially due to the uncovery of hiding catalytic triad by furin for chymotrypsin and others (Kleyman, Carattino \& Hughey, 2009; Rossier \& Stutts, 2009). Similar to furin, plasmin may cleave furin sites and expose additional proteolytic sites for itself. Our findings that long-term exposure to plasmin hydrolyses full-length ENaC proteins shifted the concept that only furin-cleaved ENaC proteins are accessible for external proteinases. This may explain why plasmin exhibited more potency to activate ENaC compared with tcuPA. Additionally, plasmin but not tc-uPA activated the G-protein pathway may facilitate ENaC activation too.

The differences between immunoblotting and functional assays in the third deletion mutants, (i.e., $\alpha \Delta 432-444$ and $\gamma \Delta 410-422$ ) could be due to the disassociation of the finger and the thumb. Removal of the GRIP domain by proteolysis results in a downward movement of the finger, subsequently hitting the thumb to enlarge the channel pore and gate. Eventually, the channel activity is up regulated maximally (Figure 9e). Even though cleavage of the GRIP domain by plasmin, as shown on Western blots, still leads to fall down of the finger, truncated thumb of these deletion mutants could not be hit by the fallen finger, which would not alter the size of channel pore and function. In addition, deletion of these putative proteolytic regions may alter the formation of channel pore. This hypothesis is supported by the first 3D model of human ENaC proteins (Noreng, Bharadwaj, Posert, Yoshioka \& Baconguis, 2018).

Our in silico prediction excludes the cleavage of human $\alpha, \delta$, and $\beta$ subunits by plasmin. To date, only $\alpha$ and $\gamma \mathrm{ENaC}$ subunits are predominately cleaved by tested proteases. Although $\delta$ subunit affects the cleavage of these two subunits, cleavage of $\delta \mathrm{ENaC}$ has not been reported. The cleavage of $\beta \mathrm{ENaC}$ by serine proteases is rare and weak (Garcia-Caballero, Dang, He \& Stutts, 2008; Jovov, Berdiev, Fuller, Ji \& Benos, 2002). Based on our in silico prediction and functional results, the possibility for plasmin to cleave $\beta$ subunit is much lesser compared with $\gamma$ counterpart.

The greater real size of C-terminal fragments on blots compared with the prediction by the server could be due to post-translational modifications. Similar to our observations, up to $110 \mathrm{kDa}$ of $\alpha \beta \gamma \mathrm{ENaC}$ proteins was described, which was even larger than what we detected. Recently, we executed mass spectrometry for the two bands of $\delta \mathrm{ENaC}$ on western blots. Both the band with a predicted size $(75 \mathrm{kDa})$ and a large band $(110 \mathrm{kDa})$ were confirmed to have $\delta \mathrm{ENaC}$ sequence (Zhao et al., 2019). Therefore, we deduce that cleavage of ENaC by plasmin could facilitate post-translational modifications. 
We could not completely rule out the involvement of protease-activated receptor-1, -2 and -4 (PAR) to fluid resolution in human and mouse lungs (Bock et al., 2015; Carmo et al., 2014; Mannaioni et al., 2008; Quinton, Kim, Derian, Jin \& Kunapuli, 2004). However, activation of lung epithelial PAR isoforms by plasmin have not been reported.

Under physiological conditions, bronchoalveolar fluid plasmin $\left(1.5 \mu \mathrm{mol} \cdot \mathrm{L}^{-1}\right)$ may activate ENaC indirectly through cleavage of sc-uPA to produce active tc-uPA. However, this possibility could be ruled out in diseased lungs. In the bronchoalveolar lavage fluid of ARDS, antiplasmin molecules, including antithrombin, $\alpha 1-$ antitrypsin, $\alpha 2$-antiplasmin, and $\alpha 2$-macroglobulin are markedly elevated. For example, $\alpha 1$-antitrypsin concentration increased 60-fold in diseased lungs (Wewers, Herzyk \& Gadek, 1988). These elevated plasmin inhibitors bound to plasmin overwhelmingly if any to cage its enzymatic activity. On the other hand, increased urokinase inhibitors, PAI-1 would form complexes with uPA and eliminate physical interactions between uPA and plasmin. Therefore, a dose above physiological concentration is needed for treating arterial occlusive diseases and macular oedema.

In summary, this study for the first time demonstrates the beneficial effects of plasmin on alveolar fluid clearance and provides novel mechanisms for how the most potent plasmin to cleave multiple sites of human $\mathrm{ENaC}$. 


\section{AUTHOR CONTRIBUTIONS}

RZ Zhao, D Bhattarai, and HL Ji expressed ENaC in oocytes, performed voltage clamp recordings, analysed AFC in mice, and analysed results. RZ Zhao carried out mutagenesis, the immunoblotting assays, and sample preparation for mass spectrometry. HG Nie performed ex vivo AFC in human lungs. G Ali performed bioelectrical assays in mouse AT2 monolayers. Y Chang performed homology modelling and protein-protein docking. HL Ji and MA Matthay were responsible for experimental design, data analysis, result assembly, and manuscript preparation.

\section{DECLARATION OF TRANSPARENCY AND SCIENTIFIC RIGOUR}

This Declaration acknowledges that this paper adheres to the principles for transparent reporting and scientific rigour of preclinical research as stated in the BJP guidelines for Design \& Analysis, Immunoblotting and Immunochemistry, and Animal Experimentation, and as recommended by funding agencies, publishers and other organisations engaged with supporting research.

\section{ORCID}

Hong-Long Ji https://orcid.org/0000-0002-3228-7144

Michael A Matthay https://orcid.org/0000-0003-3039-8155

Yongchang Chang https://orcid.org/0000-0002-4449-3383

Gibran Ali https://orcid.org/0000-0002-2997-3514

Hong-Gudang Nie https://orcid.org/0000-0002-9973-6354

Xuefeng Su https://orcid.org/0000-0002-2044-6646 
bioRxiv preprint doi: https://doi.org/10.1101/2020.02.09.940619; this version posted February 10, 2020. The copyright holder for this preprint (which was not certified by peer review) is the author/funder, who has granted bioRxiv a license to display the preprint in perpetuity. It is made available under aCC-BY-NC-ND 4.0 International license.

\section{TABLES}

Table 1. Characteristics of ENaC mutants. All of deleted and single or multiple directed mutants are included for predicted location in the 2D/3D cryo-EM model of truncated human ENaC (Noreng, Bharadwaj, Posert, Yoshioka \& Baconguis, 2018) and experimental evidence.

\begin{tabular}{|c|c|c|c|c|c|c|}
\hline Mutant (sequence) & 2D/3D location & $\begin{array}{l}\text { In silico } \\
\text { prediction }\end{array}$ & IB & $\begin{array}{l}\text { TEVC (nA): Mutant } \\
\text { vs } \alpha \beta \gamma \text { or controls }\end{array}$ & $\begin{array}{l}\text { Protein } \\
\text { docking }\end{array}$ & $\begin{array}{l}\text { Mass } \\
\text { spectrometry }\end{array}$ \\
\hline $\begin{array}{l}\alpha \Delta 173-178 \\
\text { (GSRSRR) }\end{array}$ & $\begin{array}{l}\text { Before P1 after } \alpha 1 \\
\text { /finger }\end{array}$ & - & - & $\begin{array}{l}-2,092.63 \pm 249.48 \text { vs } \\
-2,558.39 \pm 177.42\end{array}$ & - & - \\
\hline$\alpha \Delta 201-204$ (RRAR) & $\begin{array}{l}\text { P2, between } \alpha 1 \text { and } \\
\alpha 2 \text { /finger }\end{array}$ & - & - & $\begin{array}{l}-743.87 \pm 110.93 \text { vs }- \\
2,558.39 \pm 177.42\end{array}$ & - & - \\
\hline $\begin{array}{l}\alpha \Delta 432-444 \\
\text { (AYIFYPRPQNVEY) }\end{array}$ & $\begin{array}{l}\text { Between } \alpha 4 \text { and } \alpha 5 / \\
\text { thumb }\end{array}$ & - & Yes & $\begin{array}{l}-1,420.24 \pm 399.51 \text { vs } \\
-2,558.39 \pm 177.42\end{array}$ & - & - \\
\hline $\begin{array}{l}\gamma \Delta 131-138 \\
\text { (FPESRKRR) }\end{array}$ & $\begin{array}{l}\text { Before P1 after } \alpha 1 \text {, } \\
\text { with furin site /finger }\end{array}$ & Yes & Yes & $\begin{array}{l}-916.10 \pm 95.47 \text { vs }- \\
2,525.94 \pm 200.39\end{array}$ & - & R137, R138 \\
\hline $\begin{array}{l}\gamma \Delta 178-193 \text { (RKRKV } \\
\text { GGSIIHKASNV) }\end{array}$ & $\begin{array}{l}\mathrm{P} 2+, \text { between } \alpha 1 \text { and } \\
\alpha 2, / \text { finger }\end{array}$ & Yes & Yes & $\begin{array}{l}-214.09 \pm 43.84 \text { vs }- \\
2,525.94 \pm 200.39\end{array}$ & $\begin{array}{l}\text { R178, } \\
\text { R180 }\end{array}$ & $\begin{array}{l}\text { R178, K179, } \\
\text { R180, K181, } \\
\text { K189 }\end{array}$ \\
\hline $\begin{array}{l}\gamma \Delta 410-422 \text { (AQYSQP } \\
\text { LPPAANYCNYQQH } \\
\text { PNWM) }\end{array}$ & $\begin{array}{l}\text { After } \alpha 4 \text { and part of } \\
\alpha 5, / \text { thumb }\end{array}$ & - & Yes & $\begin{array}{l}-253.81 \pm 39.54 \text { vs }- \\
2,525.94 \pm 200.39\end{array}$ & - & - \\
\hline $\begin{array}{l}\gamma \Delta 131-138+3 \mathrm{~A} \\
\text { (K168A, R178A, } \\
\text { K179A) }\end{array}$ & $\begin{array}{l}\text { Before P1 after } \\
\alpha 1+\mathrm{P} 2, / \text { finger }\end{array}$ & Yes & Yes & $\begin{array}{l}-8,733.92 \pm 875.22 \text { vs } \\
-870.30 \pm 197.97\end{array}$ & $\begin{array}{l}\text { R135, } \\
\text { R137, } \\
\text { K178 }\end{array}$ & $\begin{array}{l}\text { R137, R138, } \\
\text { K168, R178, } \\
\text { K179 }\end{array}$ \\
\hline$\gamma \Delta 131-138+\mathrm{K} 168 \mathrm{~A}$ & $\begin{array}{l}\text { Before P1 and P2, } \\
\text { /finger }\end{array}$ & Yes & Yes & $\begin{array}{l}-910.22 \pm 147.01 \mathrm{vs} \\
-1,120.30 \pm 135.13\end{array}$ & $\begin{array}{l}\text { R135, } \\
\text { R137 }\end{array}$ & $\begin{array}{l}\text { R137, R138, } \\
\text { K168 }\end{array}$ \\
\hline$\gamma \Delta 131-138+\mathrm{R} 178 \mathrm{~A}$ & $\begin{array}{l}\text { Before P1 after } \\
\alpha 1+P 2 \text {, /finger }\end{array}$ & Yes & Yes & $\begin{array}{l}-1,033.91 \pm 231.72 \text { vs } \\
-1,120.30 \pm 135.13\end{array}$ & $\begin{array}{l}\text { R135, } \\
\text { R137, } \\
\text { K178 }\end{array}$ & $\begin{array}{l}\text { R137, R138, } \\
\text { R178 }\end{array}$ \\
\hline$\gamma \Delta 131-138+\mathrm{K} 179 \mathrm{~A}$ & $\begin{array}{l}\text { Before } \mathrm{P} 1 \text { after } \\
\alpha 1+\mathrm{P} 2 \text {, finger }\end{array}$ & Yes & Yes & $\begin{array}{l}-441.37 \pm 121.09 \text { vs - } \\
1,120.30 \pm 135.13\end{array}$ & $\begin{array}{l}\text { R135, } \\
\text { R137 }\end{array}$ & $\begin{array}{l}\text { R137, R138, } \\
\text { K179 }\end{array}$ \\
\hline$\gamma \mathrm{K} 126 \mathrm{~A}$ & Within $\alpha 1 /$ finger & Yes & Yes & - & - & Yes \\
\hline$\gamma \mathrm{R} 135 \mathrm{~A}$ & After $\alpha 1 /$ finger & Yes & Yes & $\begin{array}{l}-2,617.14 \pm 589.75 \text { vs } \\
-2,573.49 \pm 511.56\end{array}$ & Yes & Yes \\
\hline$\gamma \mathrm{K} 136 \mathrm{~A}$ & After $\alpha 1 /$ finger & Yes & Yes & $\begin{array}{l}-2,398.07 \pm 341.08 \text { vs } \\
-2,573.49 \pm 511.56\end{array}$ & - & Yes \\
\hline$\gamma \mathrm{R} 153 \mathrm{~A}$ & Before P1/finger & Yes & Yes & - & - & Yes \\
\hline$\gamma \mathrm{K} 168 \mathrm{~A}$ & Before P2/finger & Yes & Yes & - & - & Yes \\
\hline$\gamma \mathrm{K} 170 \mathrm{~A}$ & Before P2/finger & Yes & - & - & - & Yes \\
\hline$\gamma \mathrm{R} 178 \mathrm{~A}$ & Within P2/finger & Yes & Yes & - & Yes & Yes \\
\hline$\gamma \mathrm{K} 179 \mathrm{~A}$ & Within P2/finger & Yes & Yes & - & - & Yes \\
\hline$\gamma \mathrm{R} 180 \mathrm{~A}$ & Within P2/finger & Yes & & - & Yes & Yes \\
\hline $\begin{array}{l}\gamma \Delta 178-193+4 \mathrm{~A} \\
\text { (K126A, R135A, } \\
\text { K136A, R153A) }\end{array}$ & $\begin{array}{l}\mathrm{P} 2+\alpha 1 \text { (with furin } \\
\text { site) /finger }\end{array}$ & Yes & Yes & $\begin{array}{l}-320.15 \pm 113.04 \text { vs }- \\
299.47 \pm 152.83\end{array}$ & $\begin{array}{l}\text { R135, } \\
\text { R137, } \\
\text { R178, } \\
\text { R180 }\end{array}$ & $\begin{array}{l}\text { K126, R135, } \\
\text { K136, R153, } \\
\text { R178, K179, } \\
\text { R180, K181, } \\
\text { K189 }\end{array}$ \\
\hline $\begin{array}{l}\gamma \Delta 178-181+\mathrm{K} 189 \mathrm{~A} \\
(5 \mathrm{~A})\end{array}$ & $\mathrm{P} 2+/$ finger & Yes & Yes & $\begin{array}{l}-968.10 \pm 470.85 \text { vs }- \\
1,295 \pm 266.52\end{array}$ & $\begin{array}{l}\text { R178, } \\
\text { R180 }\end{array}$ & $\begin{array}{l}\text { R178, K179, } \\
\text { R180, K181, } \\
\text { K189 }\end{array}$ \\
\hline
\end{tabular}

Note: 2D/3D, two or three-dimensional structure. TEVC, two-electrode voltage clamp. IB, immunoblotting. Yes, positively detected/tested. - not available. 


\section{FIGURE LEGENDS}

FIGURE 1. Intratracheal administered plasmin up-regulates alveolar fluid clearance in normal human lungs. $a$. Total ex vivo 60-min alveolar fluid clearance $\left(\mathrm{AFC}_{60}\right)$ in the presence and absence (Control) of plasmin $(\mathrm{Pl}, 60$ $\mu \mathrm{g} \cdot \mathrm{ml}^{-1}, 0.7 \mu \mathrm{M} \cdot \mathrm{L}^{-1}$ ) and/or amiloride $\left(\right.$ Amil, $\left.1 \mathrm{mM} \cdot \mathrm{L}^{-1}\right)$. Adjacent human lung lobes within one biopsy specimen were selected and AFC values were measured in parallel for both control and treated groups. Data were presented as median (filled circle), mean (horizontal line), $25 \%, 75 \%$ percentile, and standard error. $* \mathrm{P}<0.05$ vs those in the absence of plasmin. NS, not significant vs both Control and Amil. $\mathrm{n}=24$. $b$. Amiloride sensitive (AS) fraction of AFC was computed as ENaC contribution in human lung lobes instilled with PBS only (Control) and plasmin. $* \mathrm{P}<0.05 . \mathrm{n}=24$.

FIGURE 2. Plasmin stimulates alveolar fluid clearance in acid aspiration injured mouse lungs. $a$. Lung water content (wet/dry ratio). Mice were intratracheally instilled $1 \mathrm{~N} \mathrm{HCl}(50 \mu \mathrm{l})$ as a model of gastric acid aspiration induced lung injury. Control animals were intratracheally delivered with $50 \mu \mathrm{PBS}$. Plasmin $\left(60 \mu \mathrm{g} \cdot \mathrm{ml}^{-1}\right.$ and 100 $\left.\mu \mathrm{g} \cdot \mathrm{ml}^{-1}\right)$ and a mixture of plasmin and equal amount of $\alpha 2$-antiplasmin $(\mathrm{Pl}+\mathrm{AP})$ were intratracheally delivered $4 \mathrm{hr}$ post $\mathrm{HCl}$ instillation. Lungs were dissected and subjected to weigh before and after dehydration. $* \mathrm{P}<0.05$. Dashed line indicates the difference vs more than one groups below. $b$. Plasmin restores in vivo 30-min $\left(\mathrm{AFC}_{30}\right)$ in mice injured by $\mathrm{HCl} . \mathrm{n}=20$. ${ }^{*} \mathrm{P}<0.05$ vs Control. \# $\mathrm{P}<0.05$ vs $\mathrm{HCl}$ group. \& $\mathrm{P}<0.05$ vs plasmin only groups.

FIGURE 3. Plasmin restores deficient ENaC activity in uPA deficient alveolar type 2 (AT2) epithelial monolayer cells. $a$. Transepithelial resistance in wt and plau $^{-/}$monolayers up to 10 days post seeding. $* * \mathrm{P}<0.01 \mathrm{vs} \mathrm{wt}$ cells. $\mathrm{n}=6 . \quad b$. Equivalent short-circuit (IEQ) in polarized AT2 monolayers cultured at the air-liquid mode. IEQ $=\mathrm{ET} / \mathrm{RT}$. ET is the transepithelial potential difference, and RT is the resistance across the monolayer read by an EVOM meter. Data were presented as mean value and standard error. NS, not significant, ${ }^{* *} \mathrm{P}<0.01$ vs wt group. $\mathrm{n}=6$. $c$. Effects of plasmin on IEQ in polarized AT2 monolayers. Data were presented as median (filled circle), mean (horizontal line), 25\%,75\% percentile, and standard error for wild type (wt), plau knockout (plau ${ }^{-/-}$), and addition of plasmin $20 \mu \mathrm{g} \cdot \mathrm{ml}^{-1}$. $* \mathrm{P}<0.05 . \mathrm{n}=5-7$.

FIGURE 4. Plasmin specifically activates human $\alpha \beta \gamma \mathrm{ENaC}$ channels expressed in Xenopus oocytes. $a$. Amiloride-sensitive sodium currents $(\mathrm{ENaC})$ were digitally sampled at the membrane potential of $-100 \mathrm{mV}$ in cells heterologously expressing human $\alpha \beta \gamma \mathrm{ENaC}$, incubated with two-chain urokinase plasminogen activator (uPA, $10 \mu \mathrm{g} \cdot \mathrm{ml}^{-1}, 30 \mathrm{~min}$ at room temperature), plasmin $\left(\mathrm{Pl}, 10 \mu \mathrm{g} \cdot \mathrm{ml}^{-1}\right)$, and a complex of plasmin $\left(\mathrm{Pl}, 10 \mu \mathrm{g} \cdot \mathrm{ml}^{-}\right.$ $\left.{ }^{1}\right)$ and $\alpha 2$-antiplasmin $\left(\alpha 2\right.$-AP, $\left.10 \mu \mathrm{g} \cdot \mathrm{ml}^{-1}\right) . \mathrm{n}=20$ per group. NS, not significant, $* \mathrm{P}<0.05$ vs controls in the absence of fibrinolytic molecules. $b$. Time course of ENaC activation by plasmin. ENaC activity in the set of oocytes was recorded at designated time points post exposure to plasmin (closed circle). $\mathrm{n}=6$ per group. $* \mathrm{P}<$ 0.05 vs the corresponding time point of controls (closed square). $c$. Effects of plasmin on the current levels of $\alpha$, $\alpha+\beta(\alpha \beta)$, and $\alpha+\gamma(\alpha \gamma)$ channels. $\mathrm{n}=10-12$. NS, not significant, $* \mathrm{P}<0.05$ vs the corresponding controls (open bar) in the absence of plasmin. $d$. Normalized incremental fold of ENaC activity. Ratio of current amplitudes recorded after over before addition of plasmin or perfusate was computed as fold of increase in channel activity. NS, not significant, $* \mathrm{P}<0.05$ vs controls. $e \& f$. Detection of full-length (F) and cleavage (C) of $\alpha$ $\mathrm{ENaC}$ by plasmin. HA (attached to the $\mathrm{N}$-terminal tail) and V5 (attached to the $\mathrm{C}$-terminal tail) tagged $\alpha$ subunit $\left(\alpha{ }^{\mathrm{V}} \mathrm{HA}\right.$ ) was co-expressed with $\beta \gamma$ subunits complementarily. Biotinylated plasma membrane proteins were run on a 7.5\% SDS-PAGE gel and probed with anti-V5 $(e)$ and anti-HA $(f)$ monoclonal antibodies. Lanes from left to right were loaded with plasma membrane proteins of cells without plasmin treatment $(\mathrm{Ctl})$, pretreated with plasmin ( $\mathrm{Pl}, 10 \mu \mathrm{g} \cdot \mathrm{ml}^{-1}$ for $30 \mathrm{~min}$ at room temperature), and chymotrypsin (Chy, $10 \mu \mathrm{g} \cdot \mathrm{ml}^{-1}$ ) as a positive control. $g \& h$. Cleavage of HA and V5 tagged $\gamma \mathrm{ENaC}\left(\gamma^{\mathrm{V} 5} \mathrm{HA}\right)$ by plasmin as recognized by anti-V5 $(g)$ and anti-HA $(h)$ antibodies. Cleaved bands are labeled with white lines at the same level. These experiments were repeated at least four times with similar observations.

FIGURE 5. Effects of plasmin on $\alpha$ and $\gamma \mathrm{ENaC}$ mutants missing consensus cleavage domains. $a$. Basal ENaC currents were recorded in oocytes expressing $\alpha \beta \gamma \mathrm{ENaC}$ and three deletion mutants lack of putative cleavage 
domains, namely, $\alpha \Delta 173-178 \beta \gamma, \alpha \Delta 201-204 \beta \gamma$, and $\alpha \Delta 432-444 \beta \gamma$. The activated currents were collected again $1 \mathrm{hr}$ post incubation with plasmin $\left(10 \mu \mathrm{g} \cdot \mathrm{ml}^{-1}, 30 \mathrm{~min}\right.$ at room temperature $)$ at the room temperature. The activated current levels were normalized to that basal currents. NS, not significant, ${ }^{*} \mathrm{P}<0.05$ vs $\alpha \beta \gamma \mathrm{ENaC} . \mathrm{n}=19-26 . b$. Activation of three $\gamma$ deletion mutants of $\alpha \beta \gamma \Delta 131-138, \alpha \beta \gamma \Delta 178-193$, and $\alpha \beta \gamma \Delta 410-422$ by plasmin. $c-f$. Immunoblotting detection of cleavage in full-length and three deletion $\gamma$ mutants. The most left lane is protein marker. Untreated cells were controls (-). Endogenous furin cleaved band in the absence of plasmin and plasmincleaved band in the presence of plasmin $(+)$ were labeled with white lines. These blots represent four experiments with similar observations. $g$. Plasmin activates the activity of mouse mutant $(\alpha \beta \gamma \mathrm{K} 189 \mathrm{~A})$ for plasmin cleavage site. Whole-cell currents were digitized and then repeated $1 \mathrm{hr}$ post incubation with plasmin $\left(10 \mu \mathrm{g} \cdot \mathrm{ml}^{-1}\right) \cdot \mathrm{n}=8$. $* \mathrm{P}<0.05$. $h$. Plasmin stimulates the activity of a human mutant $(\alpha \beta \gamma 5 \mathrm{~A})$ for plasmin cleavage (K189 and 178RKRK181 were substituted with alanine). Measurements of whole-cell currents were performed 1 and $24 \mathrm{hr}$ after exposure to plasmin. $\mathrm{n}=22, * \mathrm{P}<0.05$ vs those before addition of plasmin. $i$. Western blot assay of biotinylated plasma membrane proteins an anti-V5 monoclonal antibody. Plasma membrane proteins from noninjected oocytes (NI), cells expressing $\alpha \beta \gamma \mathrm{ENaC}$ (Control), and cells pretreated with plasmin (Plasmin) were loaded on a $7.5 \%$ SDS-PAGE gel. Furin and plasmin-cleaved proteins are pointed out with black and white rightward arrowhead, respectively. Similar results were observed in four blots.

FIGURE 6. Potential proteolysis domains for plasmin beyond the putative cleaving motif (131-138) in $\gamma$ ENaC subunit. a. In silico prediction with the database for plasmin-specific motifs. Left, a combination (logo) of reported 92 substrate motifs for plasmin from P4 to P4'. Right, a logo of input substrate sequences for plasmin from P3 to P2'. Top 10 predicted sites and the size of C-terminal fragments by both strategies are listed below. Default setup was used for running the SitePrediction server (Gosalia, Salisbury, Maly, Ellman \& Diamond, 2005; Hervio, Coombs, Bergstrom, Trivedi, Corey \& Madison, 2000). Penalty: 0.1; sort order: average score. Similarity score: 100 ; specificity, $>95 \%$. $b$. Effects of plasmin on $\alpha \beta \gamma \Delta 131-138+3 \mathrm{~A}(\mathrm{~K} 168 \mathrm{~A}, \mathrm{R} 178 \mathrm{~A}$, and K179A) channel activity in 1 and $24 \mathrm{hr} . \mathrm{n}=18$. NS, not significant, $* \mathrm{P}<0.05$ vs before. $c$. Immunoblotting assays of $\alpha \beta \gamma \Delta 131$ 138 and $\alpha \beta \gamma \Delta 131-138+3 \mathrm{~A}$ channel proteins. These results are a representative blot of three experiments. $d$. Regulation of single point mutants $(\gamma \mathrm{K} 168 \mathrm{~A}, \gamma \mathrm{R} 178 \mathrm{~A}$, and $\gamma \mathrm{K} 179 \mathrm{~A})$ derived from $\alpha \beta \gamma \Delta 131-138$ by plasmin. $\mathrm{n}=$ 12. NS, not significant vs $\alpha \beta \gamma \Delta 131-138+3 \mathrm{~A}(3 \mathrm{~A})$ construct. $e$. Detection of plasmin-cleaved fragments of three single point mutants (from left to right are $\alpha \beta \gamma \Delta 131-138, \alpha \beta \gamma \Delta 131-138+\mathrm{K} 168 \mathrm{~A}, \alpha \beta \gamma \Delta 131-138+\mathrm{R} 178 \mathrm{~A}$, and $\alpha \beta \gamma \Delta 131-138+\mathrm{K} 179 \mathrm{~A}) . f$. Cleavage efficacy (cleaved band/uncleaved band). $* * \mathrm{P}<0.01 . \mathrm{n}=3$.

FIGURE 7. Prediction and validation of putative plasmin cleaved sites preceding $\gamma \mathrm{K} 168$. a. In silico predicted four potential cleavage sites (K126, R135, K136, and R153) and the peptide size of C-terminal fragments. $b$. Effects of plasmin on the channel activity of $\alpha \beta \gamma \Delta 178-193$ and a mutant combining $\gamma \Delta 178-193$ and four predicted sites $(+4 \mathrm{~A})$ that were replaced with alanine. $\mathrm{n}=9-14$. NS, not significant vs $\alpha \beta \gamma \Delta 178-193$ mutant. $c$. Immunoblotting assays. This blot represents four experiments with similar results. $d$. Contribution of four predicted cleavage sites. $* \mathrm{P}<0.05$ vs $\alpha \beta \gamma \Delta 178-193$ construct. $\mathrm{n}=4$. $e$. Summary of newly identified and validated cleavage sites for plasmin in $\gamma \mathrm{ENaC}$ subunit. Three putative proteolytic regions for truncation mutants are marked with cylinders, four identified amino acid residues are labeled in purple font and balls.

FIGURE 8. Validation of plasmin cleaved sites by mass spectrometry. $a$. Sequences of three synthesized peptides with identified plasmin cleavage sites (red font). Three peptides with a continuous sequence were separated by two gaps. The numbers above the cleaved sites are the frequency of the fragments with an end of this amino acid residue identified by mass spectrometry. The underlines indicate the sequences of the fragments for panels $b$ to $h$ from left to right. $b-h$. MS1 spectrum for the representing fragments. The size and charge are labeled for each isotope. Corresponding sequences of each fragment occurs as insets.

FIGURE 9. Location of deletion and single or multiple point mutants in 3D model and gating mechanism. a. 3D structure of truncated human ENaC subunits adapted from Noreng $\mathrm{S} 2018$. $b$. Location of deleted regions $(\Delta 1, \Delta$ 2, and $\Delta 3$ ) for both $\alpha$ and $\gamma \mathrm{ENaC}$ subunits. $c$. Positions of identified amino acid residues for plasmin cleavage in human $\gamma$ subunit. $d-f$. Schematic mechanism for plasmin to cleave and gate ENaC protein complexes. Plasmin 
cleaves full-length $\mathrm{ENaC}(d)$ to remove the GRIP domain $(e)$. The finger domain will subsequently fall down to hit the thumb to increase the width of channel pore. $\mathrm{Na}^{+}$ions will go through channel pore faster as shown by increased currents. However, for some mutants, for example, $\Delta 3$ deletion mutants of $\alpha$ and $\gamma$ subunits, the link between the finger and the thumb disappears so that downward moved finger cannot reach the thumb to broaden channel pore $(f)$. 


\section{REFERENCES}

Alexander SP, Christopoulos A, Davenport AP, Kelly E, Marrion NV, Peters JA, et al. (2017). THE CONCISE GUIDE TO PHARMACOLOGY 2017/18: G protein-coupled receptors. Br J Pharmacol 174 Suppl 1: S17-S129.

Asakura H, Ontachi Y, Mizutani T, Kato M, Saito M, Kumabashiri I, et al. (2001). An enhanced fibrinolysis prevents the development of multiple organ failure in disseminated intravascular coagulation in spite of much activation of blood coagulation. Crit Care Med 29: 1164-1168.

Bertozzi P, Astedt B, Zenzius L, Lynch K, LeMaire F, Zapol W, et al. (1990). Depressed bronchoalveolar urokinase activity in patients with adult respiratory distress syndrome. N Engl J Med 322: 890-897.

Bock A, Tucker N, Kelher MR, Khan SY, Gonzalez E, Wohlauer M, et al. (2015). Alpha-enolase causes proinflammatory activation of pulmonary microvascular endothelial cells and primes neutrophils through plasmin activation of protease-activated receptor 2 . Shock 44: 137-142.

Carattino MD, Mueller GM, Palmer LG, Frindt G, Rued AC, Hughey RP, et al. (2014). Prostasin interacts with the epithelial $\mathrm{Na}+$ channel and facilitates cleavage of the $\gamma$-subunit by a second protease. Am J Physiol Renal Physiol 307: F1080-F1087.

Carattino MD, Sheng S, Bruns JB, Pilewski JM, Hughey RP, \& Kleyman TR (2006). The epithelial Na+ channel is inhibited by a peptide derived from proteolytic processing of its alpha subunit. J Biol Chem 281: 18901-18907.

Carmo AA, Costa BR, Vago JP, de Oliveira LC, Tavares LP, Nogueira CR, et al. (2014). Plasmin induces in vivo monocyte recruitment through protease-activated receptor-1-, MEK/ERK-, and CCR2-mediated signaling. J Immunol 193: 3654-3663.

Castellino FJ, \& Ploplis VA (2005). Structure and function of the plasminogen/plasmin system. Thromb Haemost 93: 647-654.

Chen Z, Zhao R, Zhao M, Liang X, Bhattarai D, Dhiman R, et al. (2014). Regulation of epithelial sodium channels in urokinase plasminogen activator deficiency. Am J Physiol Lung Cell Mol Physiol 307: L609-617.

Demaio L, Tseng W, Balverde Z, Alvarez JR, Kim KJ, Kelley DG, et al. (2009). Characterization of mouse alveolar epithelial cell monolayers. Am J Physiol Lung Cell Mol Physiol 296: L1051-1058.

Garcia-Caballero A, Dang Y, He H, \& Stutts MJ (2008). ENaC proteolytic regulation by channel-activating protease 2. J Gen Physiol 132: 521-535.

Gosalia DN, Salisbury CM, Maly DJ, Ellman JA, \& Diamond SL (2005). Profiling serine protease substrate specificity with solution phase fluorogenic peptide microarrays. Proteomics 5: 1292-1298.

Greenlee MM, Mitzelfelt JD, Yu L, Yue Q, Duke BJ, Harrell CS, et al. (2013). Estradiol activates epithelial sodium channels in rat alveolar cells through the G protein-coupled estrogen receptor. Am J Physiol Lung Cell Mol Physiol 305: L878-889.

Haerteis S, Krappitz M, Diakov A, Krappitz A, Rauh R, \& Korbmacher C (2012). Plasmin and chymotrypsin have distinct preferences for channel activating cleavage sites in the gamma subunit of the human epithelial sodium channel. J Gen Physiol 140: 375-389.

Haerteis S, Krueger B, Korbmacher C, \& Rauh R (2009). The delta-subunit of the epithelial sodium channel (ENaC) enhances channel activity and alters proteolytic ENaC activation. J Biol Chem 284: 29024-29040. 
Han DY, Nie HG, Gu X, Nayak RC, Su XF, Fu J, et al. (2010). K+ channel openers restore verapamil-inhibited lung fluid resolution and transepithelial ion transport. Respir Res 11: 65.

Hardaway RM, Harke H, Tyroch AH, Williams CH, Vazquez Y, \& Krause GF (2001). Treatment of severe acute respiratory distress syndrome: a final report on a phase I study. Am Surg 67: 377-382.

Harding SD, Sharman JL, Faccenda E, Southan C, Pawson AJ, Ireland S, et al. (2018). The IUPHAR/BPS Guide to PHARMACOLOGY in 2018: updates and expansion to encompass the new guide to IMMUNOPHARMACOLOGY. Nucleic Acids Res 46: D1091-D1106.

Hermans PW, Hibberd ML, Booy R, Daramola O, Hazelzet JA, de Groot R, et al. (1999). 4G/5G promoter polymorphism in the plasminogen-activator-inhibitor-1 gene and outcome of meningococcal disease. Meningococcal Research Group. Lancet 354: 556-560.

Hervio LS, Coombs GS, Bergstrom RC, Trivedi K, Corey DR, \& Madison EL (2000). Negative selectivity and the evolution of protease cascades: the specificity of plasmin for peptide and protein substrates. Chem Biol 7: 443-453.

Idell S, James KK, \& Coalson JJ (1992). Fibrinolytic activity in bronchoalveolar lavage of baboons with diffuse alveolar damage: trends in two forms of lung injury. Crit Care Med 20: 1431-1440.

Ji HL, \& Benos DJ (2004). Degenerin sites mediate proton activation of deltabetagamma-epithelial sodium channel. J Biol Chem 279: 26939-26947.

Ji HL, Parker S, Langloh AL, Fuller CM, \& Benos DJ (2001). Point mutations in the post-M2 region of human alpha-ENaC regulate cation selectivity. Am J Physiol Cell Physiol 281: C64-74.

Ji HL, Su XF, Kedar S, Li J, Barbry P, Smith PR, et al. (2006). Delta -subunit confers novel biophysical features to alpha beta gamma -human ENaC via a physical interaction. J Biol Chem 281: 8233-8241.

Ji HL, Zhao R, Komissarov AA, Chang Y, Liu Y, \& Matthay MA (2015). Proteolytic regulation of epithelial sodium channels by urokinase plasminogen activator: cutting edge and cleavage sites. J Biol Chem 290: 52415255 .

Ji HL, Zhao RZ, Chen ZX, Shetty S, Idell S, \& Matalon S (2012). Delta ENaC: a novel divergent amilorideinhibitable sodium channel. Am J Physiol Lung Cell Mol Physiol 303: L1013-1026.

Jovov B, Berdiev BK, Fuller CM, Ji HL, \& Benos DJ (2002). The serine protease trypsin cleaves C termini of beta- and gamma-subunits of epithelial Na+ channels. J Biol Chem 277: 4134-4140.

Karandashova S, Florova G, Azghani AO, Komissarov AA, Koenig K, Tucker TA, et al. (2013). Intrapleural adenoviral delivery of human plasminogen activator inhibitor-1 exacerbates tetracycline-induced pleural injury in rabbits. Am J Respir Cell Mol Biol 48: 44-52.

Kleyman TR, Carattino MD, \& Hughey RP (2009). ENaC at the cutting edge: regulation of epithelial sodium channels by proteases. J Biol Chem 284: 20447-20451.

Lim TK, \& Chin NK (1999). Empirical treatment with fibrinolysis and early surgery reduces the duration of hospitalization in pleural sepsis. Eur Respir J 13: 514-518.

Liu C, Ma Y, Su Z, Zhao R, Zhao X, Nie HG, et al. (2018). Meta-analysis of preclinical studies of fibrinolytic therapy for acute lung injury. Front Immunol 9: 1898. 
Mannaioni G, Orr AG, Hamill CE, Yuan H, Pedone KH, McCoy KL, et al. (2008). Plasmin potentiates synaptic $\mathrm{N}$-methyl-D-aspartate receptor function in hippocampal neurons through activation of protease-activated receptor1. J Biol Chem 283: 20600-20611.

Matthay MA, Folkesson HG, \& Clerici C (2002). Lung epithelial fluid transport and the resolution of pulmonary edema. Physiol Rev 82: 569-600.

Matthay MA, Ware LB, \& Zimmerman GA (2012). The acute respiratory distress syndrome. J Clin Invest 122: 2731-2740.

Molina R, Han DY, Su XF, Zhao RZ, Zhao M, Sharp GM, et al. (2011). Cpt-cAMP activates human epithelial sodium channels via relieving self-inhibition. Biochim Biophys Acta 1808: 1818-1826.

Nagase T, Uozumi N, Ishii S, Kume K, Izumi T, Ouchi Y, et al. (2000). Acute lung injury by sepsis and acid aspiration: a key role for cytosolic phospholipase A2. Nat Immunol 1: 42-46.

Noreng S, Bharadwaj A, Posert R, Yoshioka C, \& Baconguis I (2018). Structure of the human epithelial sodium channel by cryo-electron microscopy. Elife 7: e39340.

Passero CJ, Mueller GM, Myerburg MM, Carattino MD, Hughey RP, \& Kleyman TR (2012). TMPRSS4dependent activation of the epithelial sodium channel requires cleavage of the $\gamma$-subunit distal to the furin cleavage site. Am J Physiol Renal Physiol 302: F1-F8.

Passero CJ, Mueller GM, Rondon-Berrios H, Tofovic SP, Hughey RP, \& Kleyman TR (2008). Plasmin activates epithelial $\mathrm{Na}+$ channels by cleaving the gamma subunit. J Biol Chem 283: 36586-36591.

Patel BV, Wilson MR, \& Takata M (2012). Resolution of acute lung injury and inflammation: a translational mouse model. Eur Respir J 39: 1162-1170.

Planes C, \& Caughey GH (2007). Regulation of the epithelial Na+ channel by peptidases. Curr Top Dev Biol 78: 23-46.

Quinton TM, Kim S, Derian CK, Jin J, \& Kunapuli SP (2004). Plasmin-mediated activation of platelets occurs by cleavage of protease-activated receptor 4. J Biol Chem 279: 18434-18439.

Ranieri VM, Rubenfeld GD, Thompson BT, Ferguson ND, Caldwell E, Fan E, et al. (2012). Acute respiratory distress syndrome: the Berlin Definition. JAMA 307: 2526-2533.

Rossier BC, \& Stutts MJ (2009). Activation of the epithelial sodium channel (ENaC) by serine proteases. Annu Rev Physiol 71: 361-379.

Roy A, Kucukural A, \& Zhang Y (2010). I-TASSER: a unified platform for automated protein structure and function prediction. Nat Protoc 5: 725-738.

Sartori C, \& Matthay MA (2002). Alveolar epithelial fluid transport in acute lung injury: new insights. Eur Respir J 20: 1299-1313.

Schaller J, \& Gerber SS (2011). The plasmin-antiplasmin system: structural and functional aspects. Cell Mol Life Sci 68: 785-801.

Verspurten J, Gevaert K, Declercq W, \& Vandenabeele P (2009). SitePredicting the cleavage of proteinase substrates. Trends Biochem Sci 34: 319-323. 
Ware LB, \& Matthay MA (2000). The acute respiratory distress syndrome. N Engl J Med 342: 1334-1349.

Wewers MD, Herzyk DJ, \& Gadek JE (1988). Alveolar fluid neutrophil elastase activity in the adult respiratory distress syndrome is complexed to alpha-2-macroglobulin. J Clin Invest 82: 1260-1267.

Wolk KE, Lazarowski ER, Traylor ZP, Yu EN, Jewell NA, Durbin RK, et al. (2008). Influenza A virus inhibits alveolar fluid clearance in BALB/c mice. Am J Respir Crit Care Med 178: 969-976.

Zhao R, Ali G, Chang J, Komatsu S, Tsukasaki Y, Nie H-G, et al. (2019). Proliferative regulation of alveolar epithelial type 2 progenitor cells by human Scnn1d gene. Theranostics 9: 8155-8170. 
Figure 1
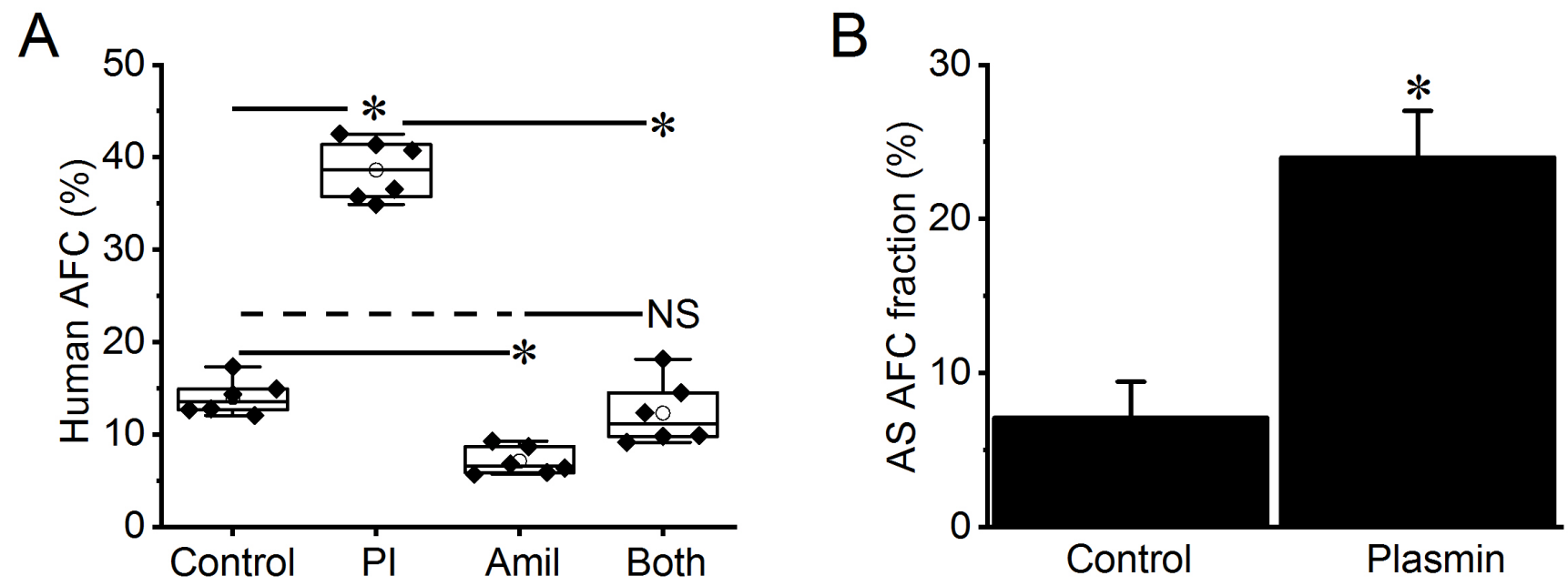
Figure 2
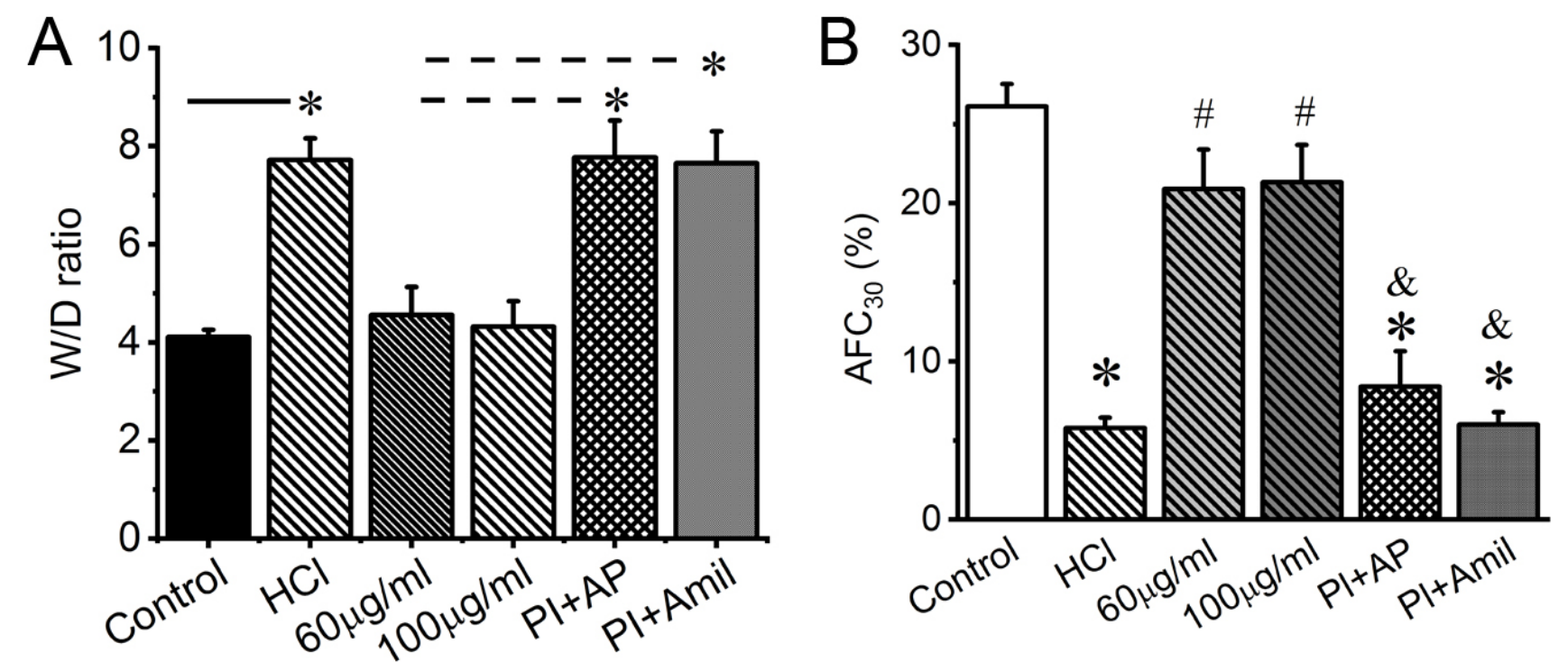
Figure 3

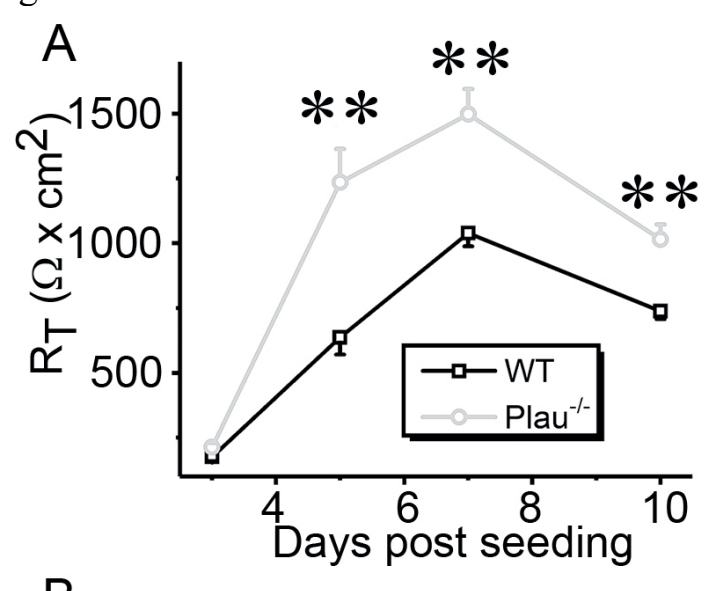

B
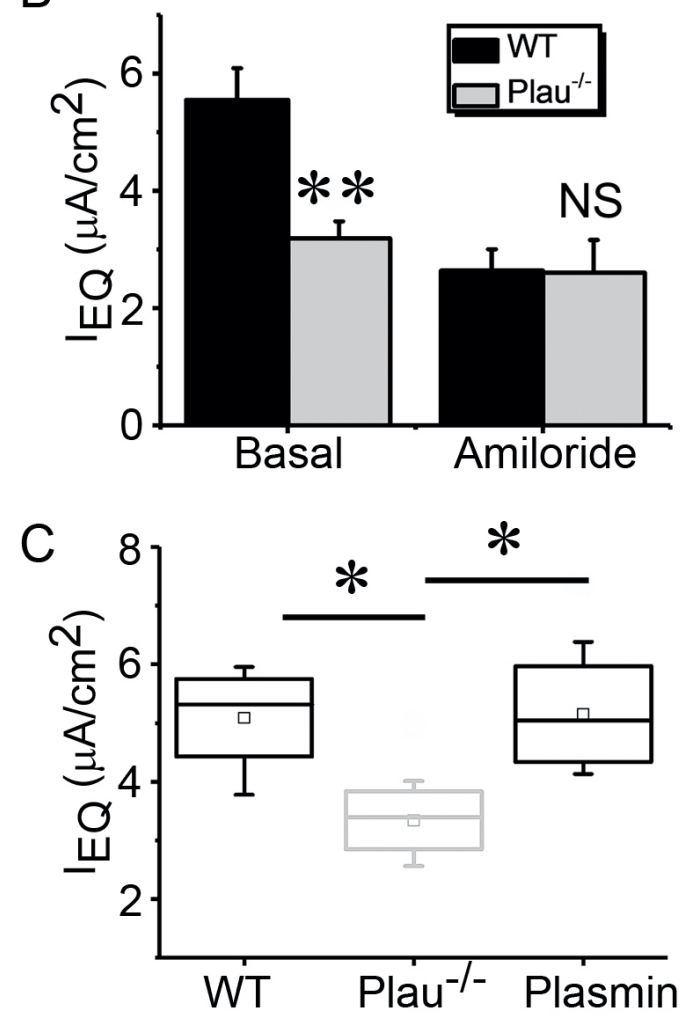
Figure 4

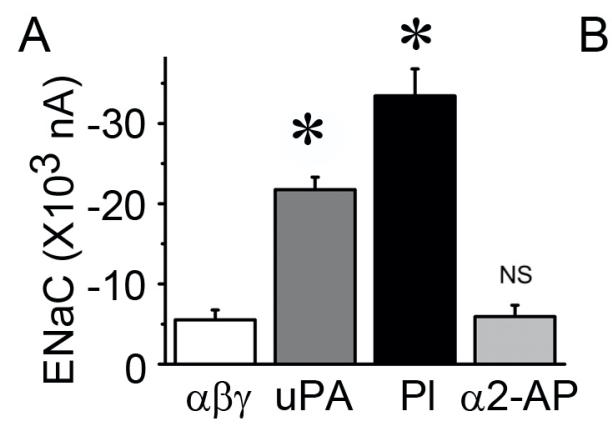

C

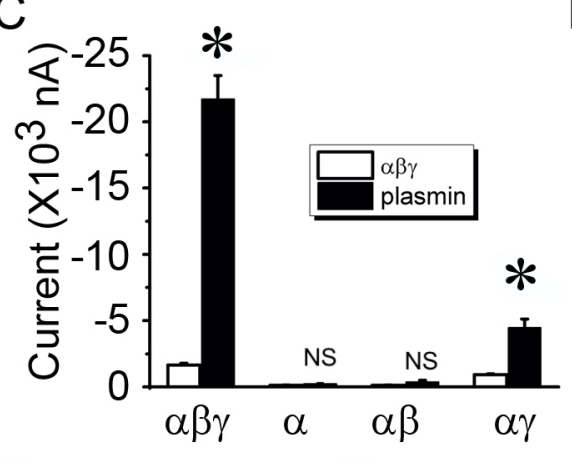

D
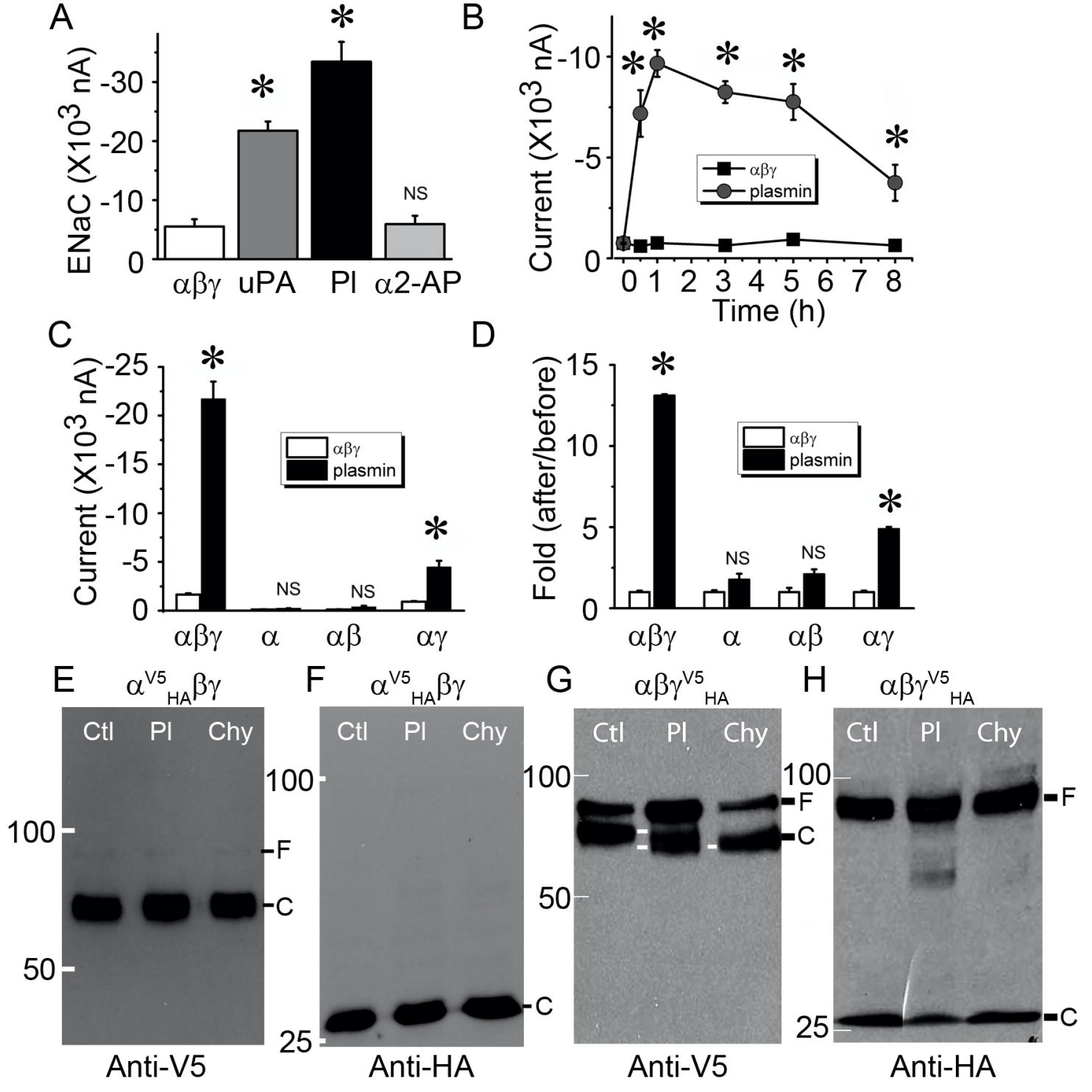
Figure 5

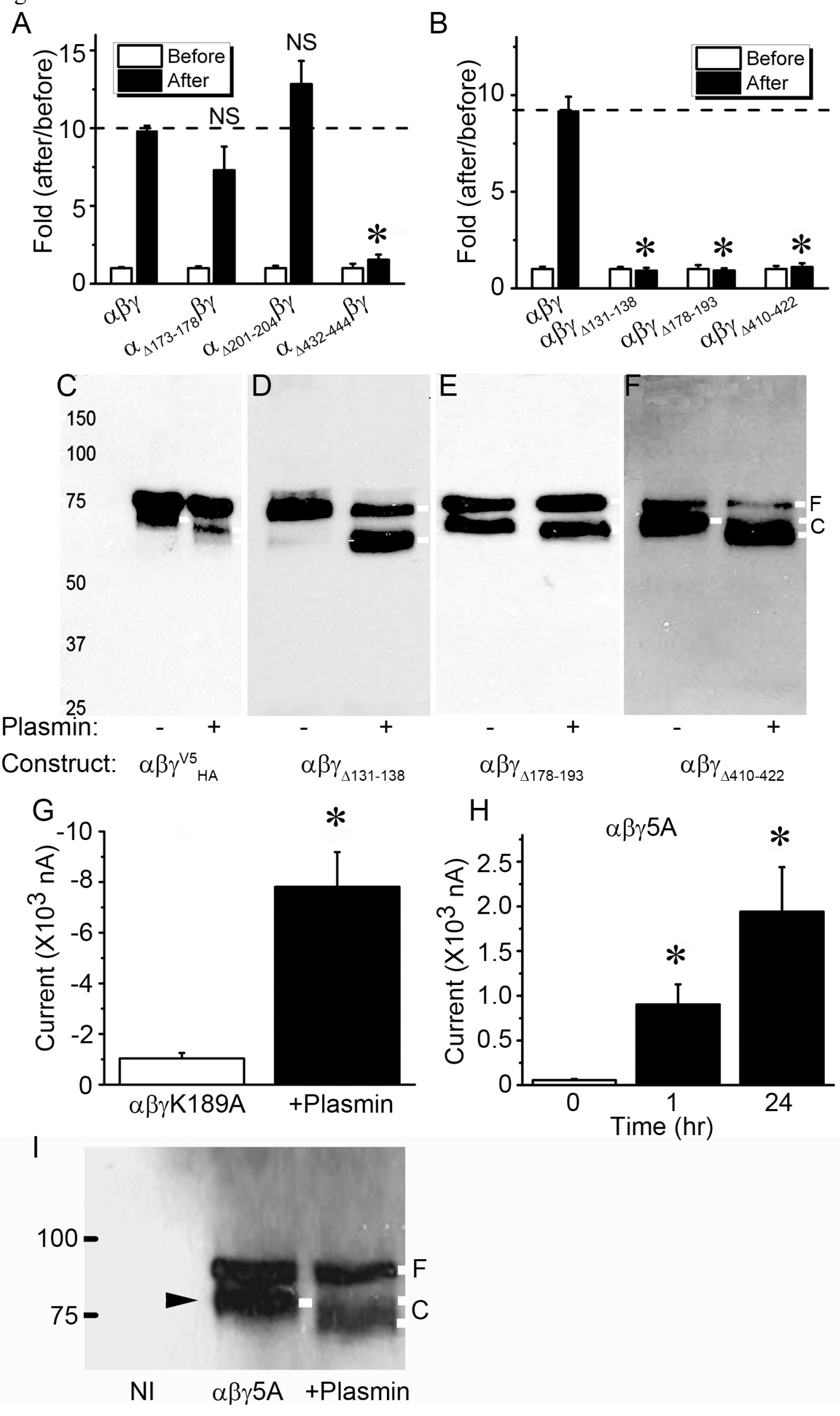


Figure 6

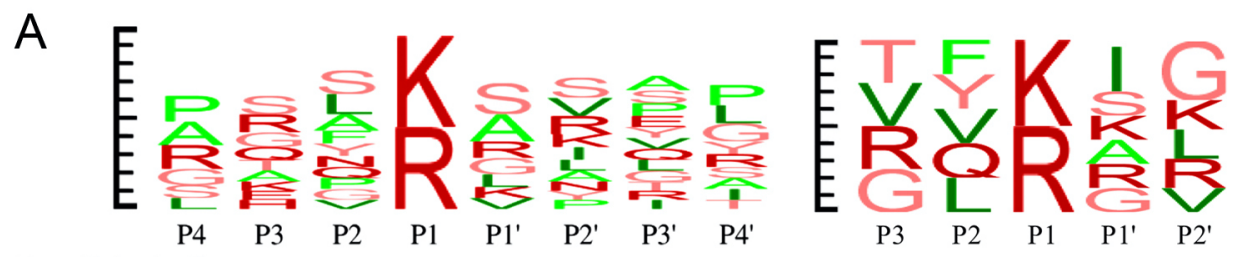

Predicted sites: ${ }^{165}$ QDEK168.GK170.ARDFXTGR178.K179.R180.K181.VGGS ${ }^{185}$ Size of C-tail $(\mathrm{kDa}): \quad 54.8 \quad 54.6$

$\begin{array}{llll}53.6 & 53.5 & 53.3 & 53.2\end{array}$

$\mathrm{B}$

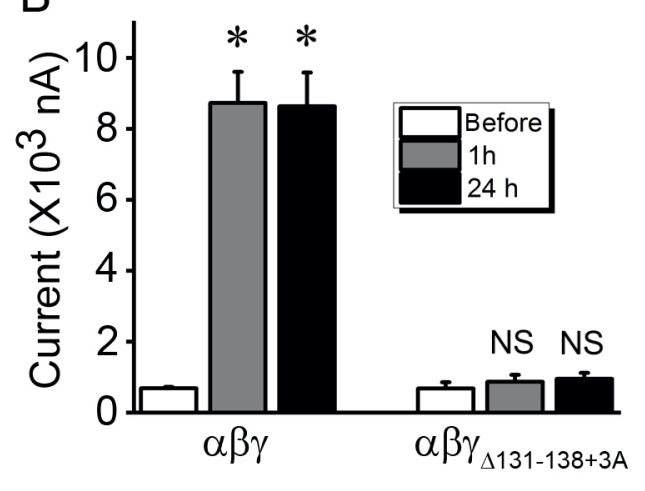

D

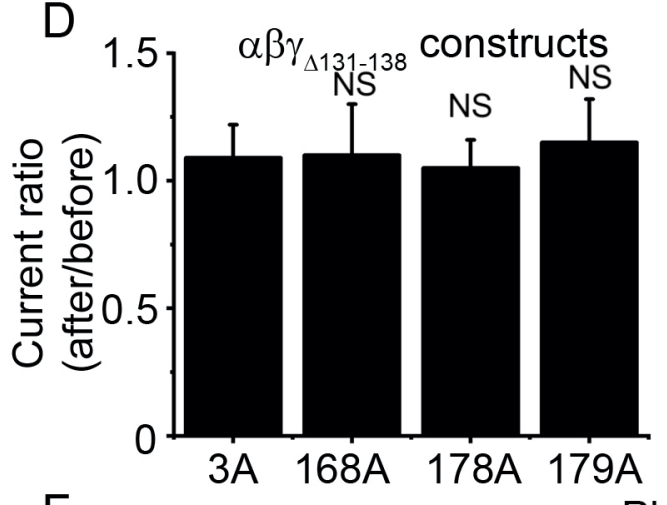

$\mathrm{F}$

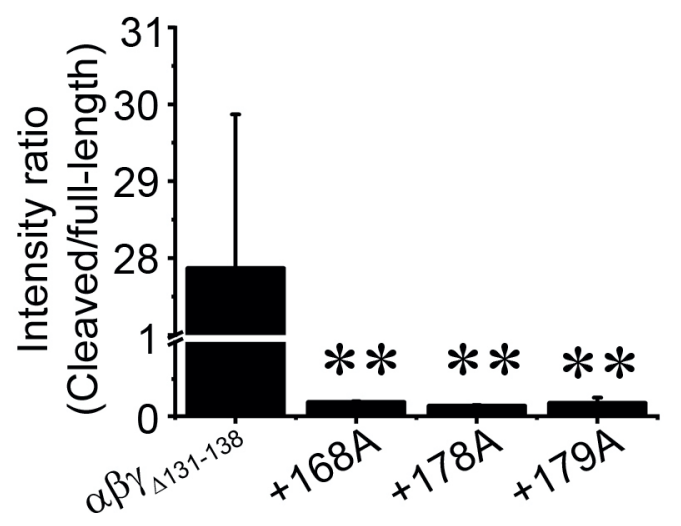

C $\quad \alpha \beta \gamma_{\triangle 131-138}+3 \mathrm{~A}$

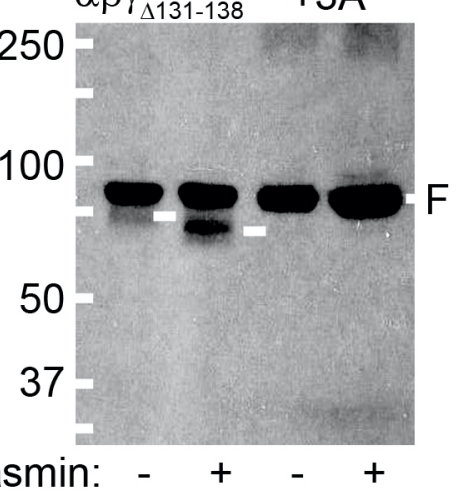

E

$\triangle 131-138$ 168A 178A 179A

100

50

Plasmin: $+\quad+\quad+\quad+$ 
bioRxiv preprint doi: https://doi.org/10.1101/2020.02.09.940619; this version posted February 10, 2020. The copyright holder for this preprint (which was not certified by peer review) is the author/funder, who has granted bioRxiv a license to display the preprint in perpetuity. It is made available under aCC-BY-NC-ND 4.0 International license.

Figure 7
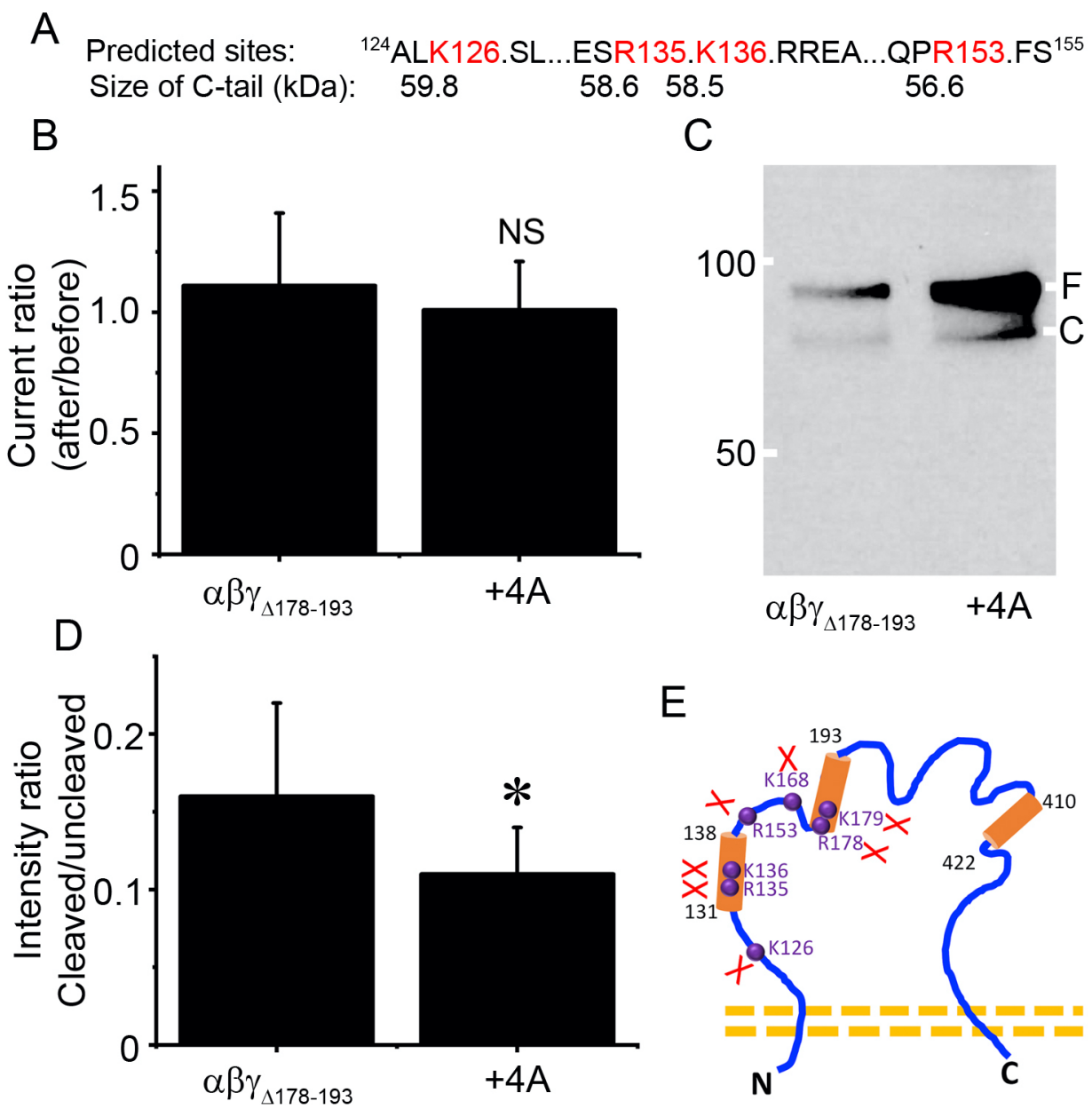
bioRxiv preprint doi: https://doi org/10.1101/2020.02 09 940619; this version posted February 10,2020 . The copyright holder for this preprint (which was not certified by peer review) is the author/funder, who has granted bioRxiv a license to display the preprint in perpetuity. It is made available under aCC-BY-NC-ND 4.0 International license.

Figure 8

\section{A}

$275 \quad 354$

$659 / 322 / 9 / 9$

4236

218/760/56 650/238/308/100 171

${ }^{121}$ TREALKSLYGFPESRKRREAESWN SVSEGKQPRFSHRIPLL IFDQDEKGKARDFFTGRKRKVGGSIIHKA ${ }^{190}$

B

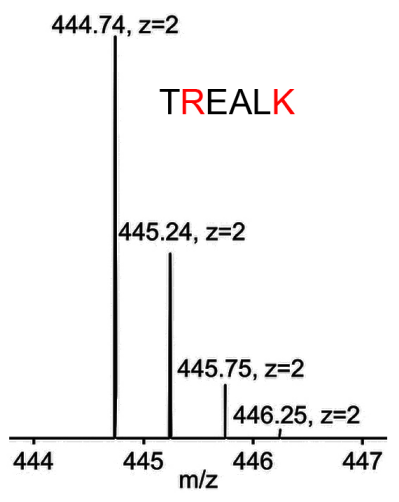

C

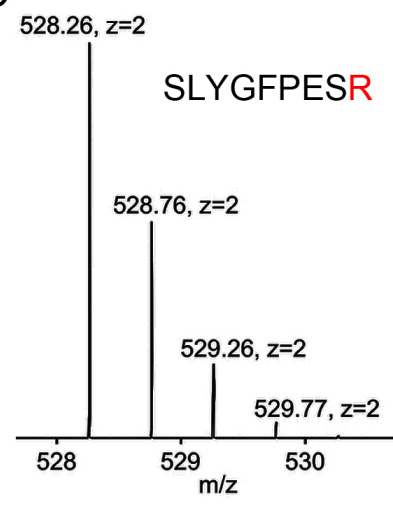

$515.27, \mathrm{z}=2$

$\mathrm{D}$

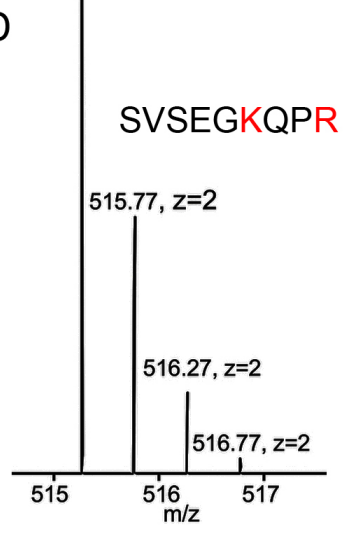

$\mathrm{H}$

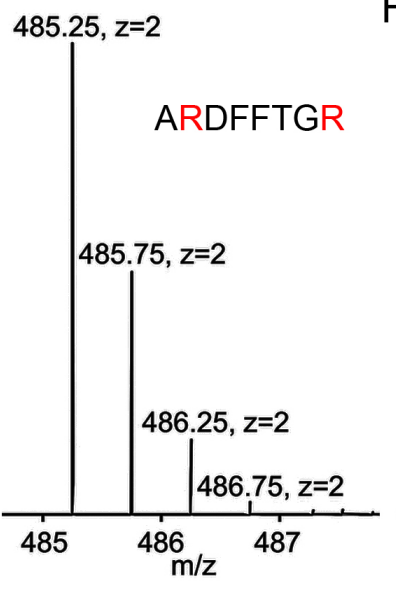

408.26, $z=3$

KRKVGGSIIHK

408.60, $z=3$

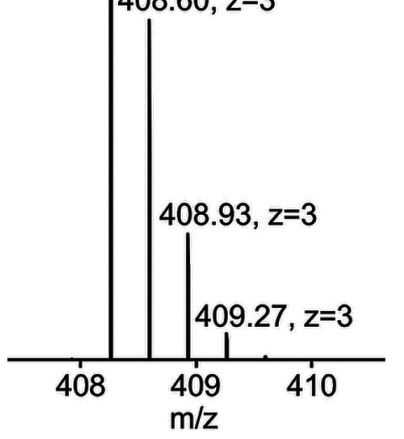

E

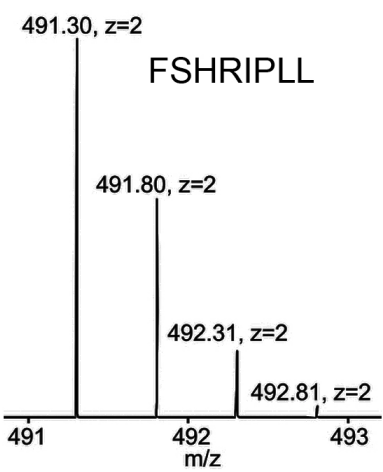

F

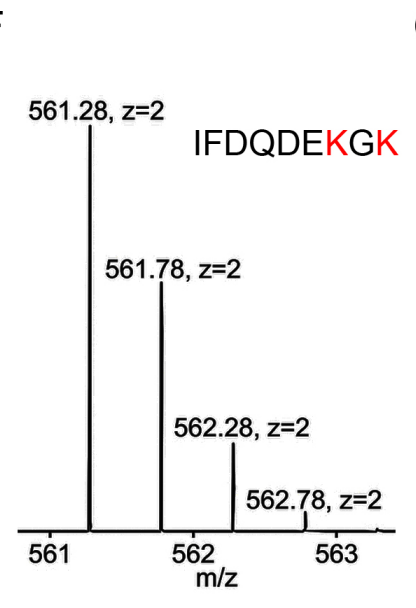

\section{G}


bioRxiv preprint doi: https://doi.org/10.1101/2020.02.09.940619; this version posted February 10, 2020. The copyright holder for this preprint (which was not certified by peer review) is the author/funder, who has granted bioRxiv a license to display the preprint in perpetuity. It is made available under aCC-BY-NC-ND 4.0 International license.

Figure 9
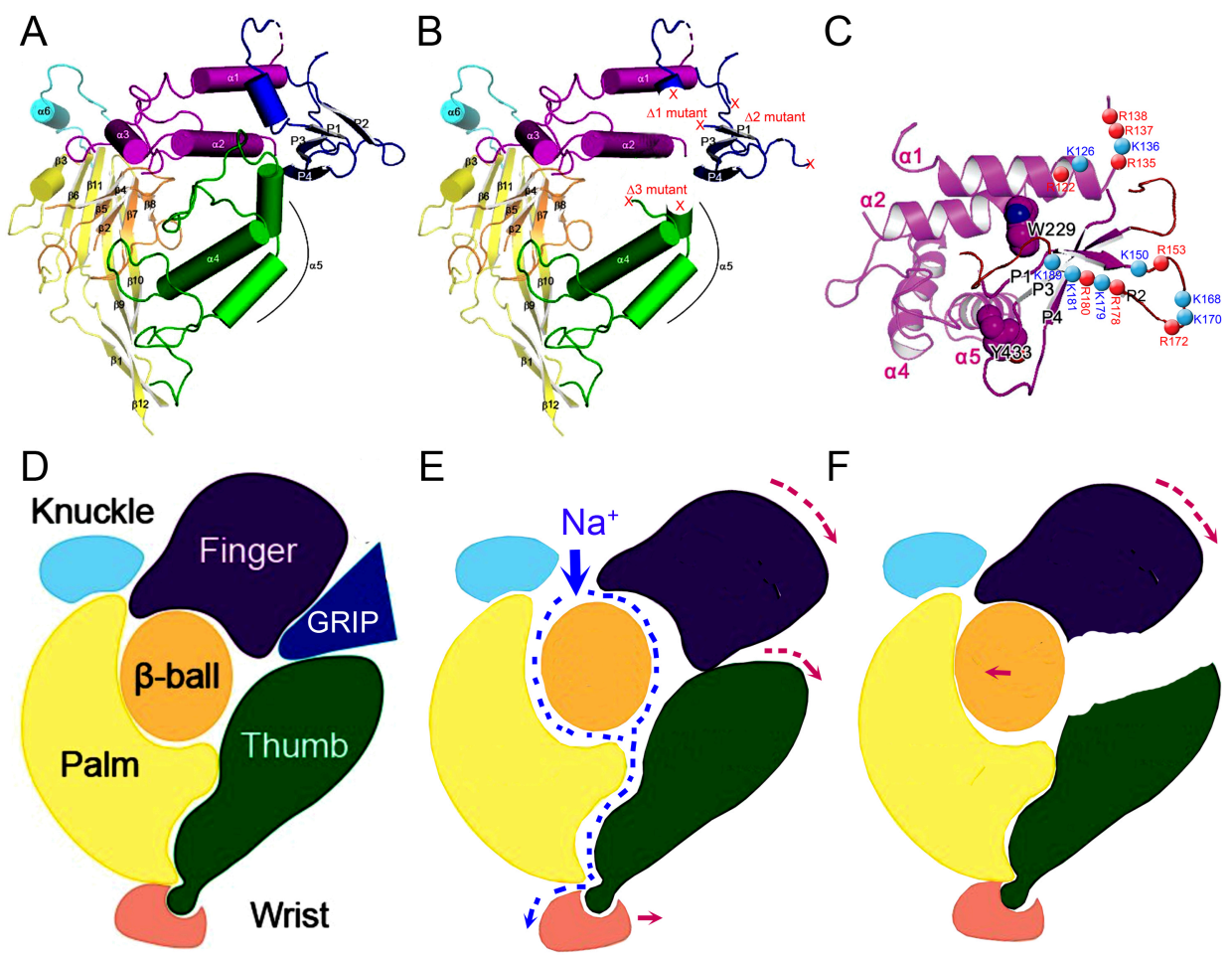